Article

\title{
Nutritional and Functional Evaluation of Inula crithmoides and Mesembryanthemum nodiflorum Grown in Different Salinities for Human Consumption
}

 \\ Tamára Santos $^{2}$, Miguel Salazar ${ }^{3}$, Carla Nunes ${ }^{3}$, Rui M. S. Cruz ${ }^{1}$, João Varela ${ }^{2} \mathbb{D}$ and Luísa Barreira ${ }^{2, *(\mathbb{D})}$ \\ 1 MED-Mediterranean Institute for Agriculture, Environment and Development, Universidade do Algarve, \\ Campus da Penha, 8005-139 Faro, Portugal; carlima@ualg.pt (A.R.L.); fmgama@ualg.pt (F.G.); \\ rcruz@ualg.pt (R.M.S.C.) \\ 2 CCMAR-Centre of Marine Sciences, Campus de Gambelas, Universidade do Algarve, 8005-139 Faro, Portugal; \\ vcloaiza@ualg.pt (V.C.-L.); cqcosta@ualg.pt (C.C.); lmschueler@ualg.pt (L.M.S.); tfsantos@ualg.pt (T.S.); \\ jvarela@ualg.pt (J.V.) \\ 3 RiaFresh, Sítio do Besouro, CX 547-B, 8005-241 Faro, Portugal; miguel.salazar@agro-on.pt (M.S.); \\ carla.nunes@agro-on.pt (C.N.) \\ * Correspondence: lbarreir@ualg.pt; Tel.: +351-289-800-900 (ext. 7385)
}

Citation: Lima, A.R.; Gama, F.; Castañeda-Loaiza, V.; Costa, C.; Schüler, L.M.; Santos, T.; Salazar, M.; Nunes, C.; Cruz, R.M.S.; Varela, J.; et al. Nutritional and Functional Evaluation of Inula crithmoides and Mesembryanthemum nodiflorum Grown in Different Salinities for Human Consumption. Molecules 2021, 26 , 4543. https://doi.org/10.3390/ molecules 26154543

Academic Editor: Christian Magné

Received: 29 June 2021

Accepted: 25 July 2021

Published: 27 July 2021

Publisher's Note: MDPI stays neutral with regard to jurisdictional claims in published maps and institutional affiliations.

Copyright: (c) 2021 by the authors. Licensee MDPI, Basel, Switzerland. This article is an open access article distributed under the terms and conditions of the Creative Commons Attribution (CC BY) license (https:/ / creativecommons.org/licenses/by/ $4.0 /)$.

\begin{abstract}
The nutritional composition and productivity of halophytes is strongly related to the biotic/abiotic stress to which these extremophile salt tolerant plants are subjected during their cultivation cycle. In this study, two commercial halophyte species (Inula crithmoides and Mesembryanthemum nodiflorum) were cultivated at six levels of salinity using a soilless cultivation system. In this way, it was possible to understand the response mechanisms of these halophytes to salt stress. The relative productivity decreased from the salinities of 110 and $200 \mathrm{mmol} \mathrm{L}^{-1}$ upwards for I. crithmoides and M. nodiflorum, respectively. Nonetheless, the nutritional profile for human consumption remained balanced. In general, I. crithmoides vitamin (B1 and B6) contents were significantly higher than those of $M$. nodiflorum. For both species, $\beta$-carotene and lutein were induced by salinity, possibly as a response to oxidative stress. Phenolic compounds were more abundant in plants cultivated at lower salinities, while the antioxidant activity increased as a response to salt stress. Sensory characteristics were evaluated by a panel of culinary chefs showing a preference for plants grown at the salt concentration of $350 \mathrm{mmol} \mathrm{L}^{-1}$. In summary, salinity stress was effective in boosting important nutritional components in these species, and the soilless system promotes the sustainable and safe production of halophyte plants for human consumption.
\end{abstract}

Keywords: halophytes; soilless cultivation; salinity stress; nutritional composition; bioactive compounds; sensory profile

\section{Introduction}

Halophytes are plants known to grow in naturally saline habitats, where $99 \%$ of salt-sensitive species die due to $\mathrm{NaCl}$ toxicity [1]. Furthermore, despite the interspecific variability found, it is known that the biomass of several halophyte species have shown good phenolic contents, and an ability to scavenge superoxide anions or other free radicals [2,3]. As a result, these plants have become excellent candidates for human consumption, with properties suitable for pharmacological use, boosting the interest of producers and consumers in the cultivation of these species.

Inula crithmoides L. (syn. Limbarda crithmoides L. Dumort.) is a halophyte belonging to the family Asteraceae. It is a dicotyledonous succulent plant commonly found in saltwater marsh areas on the Mediterranean basin [4]. Mesembryanthemum nodiflorum L. is another halophyte that grows in a similar habitat and is a species belonging to the Aizoaceae family, which has widespread use in traditional Tunisian medicine as an antiseptic for oral 
infections, stomach problems, wounds, and burns [5]. In Portugal, both species are found along the coastal area and in saltwater marshes, which are zones with extremely saline soil. The tolerance of these species to salt is associated with their osmoregulatory function from the accumulation of betaine, glycine, and proline [6]. In addition, both plants have large contents of secondary metabolites exhibiting different bioactivities, such as those shown by Inula spp. extracts with proven antibacterial, antioxidant, antifungal, and cytotoxic activities [7], while Mesembryanthemum spp. extracts are associated with antioxidant and antiviral activities $[3,8]$.

In a more general context, both wild halophyte plants and those cultivated under controlled conditions have a nutritional profile suitable for human consumption, with low fat content and high concentrations of protein, fiber, and minerals [9], being rich in bioactive compounds [10] as well. In this sense, the growing interest in halophytes for human consumption and pharmacological and cosmetic use not only places these plants in a prominent position at the scientific level but also in an industrial context. However, there is a justifiable concern that increased knowledge of the health benefits of halophytes may lead to their abusive collection from natural habitats, causing an environmental imbalance.

Hence, cultivation using salinized soils not suitable for conventional agriculture or cultivation in soilless systems as a sustainable and eco-friendly solution presents itself as a crucial strategy to not only preserve the environment from possible consumers of these plants but also to promote the agricultural production sector. This type of agriculture is particularly interesting in areas characterized by limited availability of water [11], as is the case of the Algarve, a region in the south of Portugal with growing interest in the production of halophyte plants. Cultivation in soilless systems has additional advantages in terms of increased productivity, product uniformity, and food security [11,12], as it enables the control and avoidance of hyperaccumulation of heavy metals by several halophyte species [13]. Currently, in Portugal, there are several ventures for halophyte production using different cultivation methods, which include controlled soil, hydroponics, and soilless systems. One of the most successful ventures is RiaFresh, which produces Inula crithmoides, Mesembryanthemum nodiflorum, and Salicornia ramosissima J. Woods, among other species, all cultivated using a soilless system and aimed for human consumption.

Since in halophyte plants, the accumulation and synthesis of nutrients are generally stimulated in response to biotic and abiotic stresses such as salinity [14,15], this study aimed to evaluate the influence of salinity on productivity and the nutritional and sensory properties of I. crithmoides and M. nodiflorum grown in greenhouses using a soilless system. This information was used to find the conditions for the optimal cultivation of I. crithmoides and M. nodiflorum, not only in terms of productivity, but also to obtain a balanced nutritional composition, attractive sensory characteristics, and a suitable content of bioactive compounds. Both species are commercially produced and used in gourmet cuisine; the growing interest of consumers on these plants and their relevance for the Mediterranean diet as sustainable sources of fiber, proteins, together with the poor knowledge regarding the most appropriate cultivation conditions for the optimum nutritional properties motivated this study. Taken together, the results here reported will contribute to a sustainable culture while promoting the consumption of these plants as a healthier substitute for salt.

\section{Results and Discussion}

\subsection{Effects of Salinity on Productivity}

Upon testing different growth conditions, plant growth was mainly affected by salinity. I. crithmoides showed a significant decrease in plant height for salinity levels over $35 \mathrm{mmol} \mathrm{L}^{-1}$. Conversely, $M$. nodiflorum plants were more comparable in size at different salinities, although a reddish color in the stems (Figure 1) could be observed, becoming more intense at higher salinities. This is a trait often observed in plants of this genus and is generally associated with the accumulation of water-soluble pigments belonging to the betacyanins group, which are commonly produced in response to salinity [16]. Moreover, the response to salinity was species-dependent, as salinity clearly compromised relative 
productivity to a greater extent in I. crithmoides as compared to what was observed in M. nodiflorum (Table 1).



(a)



(b)

Figure 1. M. nodiflorum cultivated with the $35 \mathrm{mmol} \mathrm{L}^{-1}$ (a) and $465 \mathrm{mmol} \mathrm{L}^{-1}$ (b) nutrient solutions. The accumulation of reddish pigments in the stems becomes evident as the salinity is increased.

Table 1. Relative productivity, electric conductivity, texture, and proximate composition of the samples cultivated at six different salinities. Values are presented as means \pm SEM.

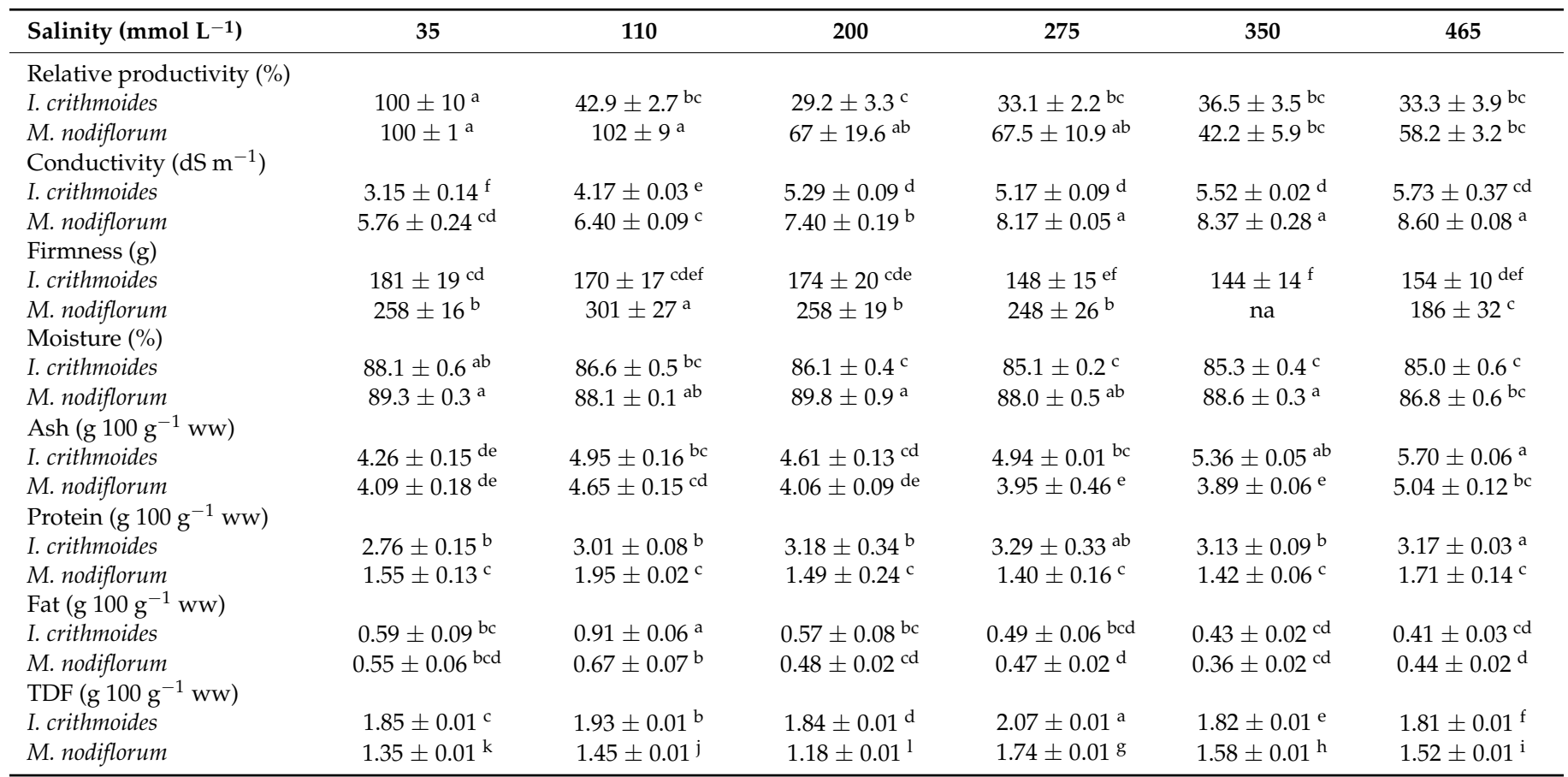

na: not available; ww: wet weight; TDF: total dietary fiber; In each analysis (two lines), different letters indicate significant differences between different salinities $(p<0.05)$. 
In this study, I. crithmoides had maximum productivity at the lowest salinity ( $35 \mathrm{mmol} \mathrm{L}^{-1}$ ), whereas for $M$. nodiflorum, the maximum productivity was attained between salinities of $35-110 \mathrm{mmol} \mathrm{L}^{-1}$. In I. crithmoides, the relative productivity decreased by $57 \%$ when the salinity was increased from 35 to $110 \mathrm{mmol} \mathrm{L}^{-1}$. Regarding the highest salinity (465 $\mathrm{mmol} \mathrm{L}^{-1}$ ), the relative productivity decreased by $66 \%$ and $42 \%$, respectively, for each species. These results show a stronger impact of salinity on productivity than the findings of Zurayk and Baalbaki [4], where the growth of potted I. crithmoides at different levels of salinity for a period of 87 days was only affected by water with an electric conductivity (EC) exceeding $20 \mathrm{dS} \mathrm{m}^{-1}$ (salinity $\approx 200 \mathrm{mmol} \mathrm{L}^{-1}$ ). Although, in a study on Inula viscosa L. by Curadi et al. [17], they observed a consistent decrease in biomass production caused by salt; irrigation water with an EC of $12 \mathrm{dS} \mathrm{m}^{-1}$ (salinity $\approx 120 \mathrm{mmol} \mathrm{L}^{-1}$ ) led to a $42 \%$ decrease compared to control plants where salt addition was omitted. Regarding M. nodiflorum, we were not able to find a comparable study, but with a related species, $M$. crystallinum, Atzori et al. [18] observed that seawater irrigation up to an EC of $35 \mathrm{dS} \mathrm{m}^{-1}$ did not impact plant growth. Although M. nodiflorum does not have enlarged unicellular trichomes in the leaves and stems, also called bladder cells, as M. crystallinum, it has narrow succulent-like leaves that also act as water reservoirs, providing protection from short-term high salinity or water deficit stress.

\subsection{Proximate Composition and Firmness}

The effect of salinity on the proximal composition of I. crithmoides and M. nodiflorum is shown in Table 1 . The moisture content of both plants was similar at low $\left(35 \mathrm{mmol} \mathrm{L}^{-1}\right)$ and at high $\left(465 \mathrm{mmol} \mathrm{L}^{-1}\right)$ salinities. However, the increase in the amount of salt available to the plants promoted a significant reduction in the moisture content of both species. These results corroborate those obtained in similar studies with other halophyte species, such as Salicornia ramosissima, S. europaea and S. persica. Indeed, this lower moisture content can be attributed to the osmotic imbalance caused by the reduction in water uptake by the plant cells upon exposure to large amounts of $\mathrm{NaCl}[19,20]$.

The salt concentration of the cultivation medium significantly influenced ash content. According to Attia-Ismail [21], a high ash content is typical of halophytes, and in this case, can be attributed to the large capacity for mineral accumulation by these plants. In this study, I. crithmoides and M. nodiflorum had the highest ash content, 5.70 and $5.04 \mathrm{~g} 100^{-1}$ wet weight (ww), respectively, at $465 \mathrm{mmol} \mathrm{L}^{-1}$ (Table 1). However, in addition to the significant difference observed between species, with I. crithmoides presenting the highest content, M. nodiflorum ash content remained approximately constant up to the salinity of $350 \mathrm{mmol} \mathrm{L}^{-1}$, suggesting that this species is able to counteract the accumulation of salts in its tissues until the latter salinity is reached. Conversely, I. crithmoides ashes underwent a gradual increase, strongly suggesting that this species may use a different regulatory mechanism for osmoregulation.

Inula crithmoides had higher amounts of protein than M. nodiflorum. Moreover, an increase in the crude protein content, around 14-19\% compared to the samples cultivated at the lowest salinity, was observed in plants cultivated at the three highest salinities tested $\left(275,350\right.$, and $\left.465 \mathrm{mmol} \mathrm{L}^{-1}\right)$, indicating that I. crithmoides was significantly affected by the increase in salt stress (Table 1). A similar response was reported by Agudelo et al. [13] for three species of halophytes (Atriplex halimus, Salicornia fruticosa, and Cakile maritima) under salt stress between 0 and $300 \mathrm{mmol} \mathrm{L}^{-1}$. Salinity appears to have had a lower impact on the protein content of $M$. nodiflorum, as no significant differences between samples were observed. Similarly, Lima et al. [20] and Ventura et al. [22] observed that the protein contents of S. persica and S. ramosissima were also unaffected by salt stress. Although these results suggest an interesting stability in terms of total protein content, many studies have reported that halophytes can display distinct coordinate proteomic responses to salinity. Indeed, besides their role in the structural organization of the cell and metabolism, proteins are key regulators of cellular responses to salt stress, which may range from the induction 
of heat shock proteins with the ability to avoid protein denaturation to higher expression of genes encoding ion transporters [23-25].

Overall, the lipid content of these halophyte plants was low [26]. However, there is a trend toward an increase in lipids in plants grown under greenhouse and outdoor farming conditions compared to wild plants $[9,27]$. In this study, despite the range of salt stress levels used, the lipid contents of both species grown at different salinities were not strikingly different. Only the plants cultivated at $110 \mathrm{mmol} \mathrm{L}^{-1}$ had higher fat contents than those at other salinities (Table 1). Total dietary fiber (TDF) includes, in addition to oligosaccharides and polysaccharides, other classes of associated plant molecules in their composition, such as cutins, lignins, and suberines [28,29]. Several studies have reported that wild halophyte plants tend to have higher fiber contents than plants grown under controlled conditions $[9,20,30]$. One factor that stimulates the production of structural fibers in wild halophytes is exposure to abiotic conditions, especially wind, which is often absent in controlled environments such as greenhouses. Conversely, controlled cultivation conditions provide a greater supply of nutrients, increasing the growth rate and reducing the investment in the production of structural polysaccharides, such as cellulose and lignin $[19,20]$. In this study, both species cultivated at $275 \mathrm{mmol} \mathrm{L}^{-1}$ showed higher fiber content. However, under higher salt stress ( 350 and $465 \mathrm{mmol} \mathrm{L}^{-1}$ ), the plants showed a slight decrease in fiber content, hinting that mild salt stress can stimulate the production of structural components by plants, but excess salt reduces the production of structural polysaccharides.

The firmness parameter for I. crithmoides ranged from $181 \pm 19\left(35 \mathrm{mmol} \mathrm{L}^{-1}\right)$ to $154 \pm 10\left(465 \mathrm{mmol} \mathrm{L}^{-1}\right)$ and for M. nodiflorum from $258 \pm 16\left(35 \mathrm{mmol} \mathrm{L}^{-1}\right)$ to $186 \pm 32$ $\left(465 \mathrm{mmol} \mathrm{L}^{-1}\right)$, as shown in Table 1 . In sensory and gastronomic terms, firmness is one of the main physical properties that explain the texture of a product [30]. For the studied halophytes, this property was used to evaluate the substantial resistance to deformation and hardness of the plants and by how much salinity can influence these characteristics. Overall, firmness was inversely correlated with cultivation salinity, again a strong indication that salt stress conditions reduce the formation of structural components of plants (i.e., cellulose and lignin), decreasing their firmness and influencing their palatability $[9,19]$. This result is unlike what is usually seen in edible fibers, which do not include cellulose, but include other small oligosaccharides that may have been induced in response to exposure to moderate concentrations of salt. Moreover, the significantly higher firmness of M. nodiflorum plants compared to that of I. crithmoides can be attributed to other characteristics such as the presence of a stomatal complex capable of performing day and night movements for osmotic regulation, water absorption, and accumulation of carbon dioxide [30], different from those present in the lanceolate and cracked leaves of the I. crithmoides [4].

\subsection{Minerals}

The minerals composition of the studied halophyte species is shown in Table 2. As expected, $\mathrm{Na}$ was the element present in larger quantities in both halophyte species. $\mathrm{K}$ was the second most abundant element in this analysis. In both plants, Na content was approximately twice as high in the condition of maximum salt stress $(465 \mathrm{mmol} \mathrm{L}-1)$ compared to that of plants cultivated at the lowest salinity $\left(35 \mathrm{mmol} \mathrm{L}^{-1}\right)$. This increase was not seen for the $\mathrm{K}, \mathrm{Ca}$, and $\mathrm{Mg}$.

The increase in $\mathrm{Na}$ and the reduction in $\mathrm{K}, \mathrm{Ca}$, and $\mathrm{Mg}$ is reported in the literature for other species of halophyte plants subjected to different levels of salt stress during cultivation [13,20]. According to Flowers and Colmer [1], the decrease in $\mathrm{K}, \mathrm{Ca}$, and $\mathrm{Mg}$ can be associated with an inhibition of the accumulation of other macroelements due to excess sodium, resulting in an increase in the $\mathrm{Na}: \mathrm{K}$ ratio upon exposure to salt stress, as observed in the studied species (Table 2). A similar link was observed by Katschnig et al. [31] in Salicornia dolichostachya. Other studies have observed that $\mathrm{NaCl}$ stress promotes a competition between $\mathrm{Na}+$ and $\mathrm{K}+$ upon their uptake by the plant, being responsible 
for influencing the activation of osmolytes that seek the osmotic balance of the plant, promoting a drop in the endogenous $\mathrm{K}+$ levels [32,33].

Table 2. Mineral composition of I. crithmoides and M. nodiflorum cultivated at six different salinities.

\begin{tabular}{|c|c|c|c|c|c|c|}
\hline $\begin{array}{l}\text { Salinity } \\
\left(\text { mmol L }^{-1}\right)\end{array}$ & 35 & 110 & 200 & 275 & 350 & 465 \\
\hline \multicolumn{7}{|c|}{ Inula crithmoides } \\
\hline $\mathrm{Na}\left(\mathrm{mg} \mathrm{g}^{-1}\right)$ & $7.01 \pm 0.7^{\mathrm{d}}$ & $8.95 \pm 0.2^{c}$ & $12.0 \pm 0.1^{b}$ & $13.5 \pm 0.4^{\mathrm{a}}$ & $13.7 \pm 0.1^{\mathrm{a}}$ & $14.4 \pm 0.2^{\mathrm{a}}$ \\
\hline $\mathrm{K}\left(\mathrm{mg} \mathrm{g}^{-1}\right)$ & $3.10 \pm 0.33^{\mathrm{a}}$ & $3.13 \pm 0.02^{a b}$ & $2.55 \pm 0.04^{b c}$ & $2.78 \pm 0.13^{c}$ & $2.67 \pm 0.01^{c}$ & $2.68 \pm 0.08^{c}$ \\
\hline $\mathrm{Ca}\left(\mathrm{mg} \mathrm{g}^{-1}\right)$ & $1.58 \pm 0.13^{\mathrm{a}}$ & $1.46 \pm 0.01^{\mathrm{ab}}$ & $1.33 \pm 0.01^{b}$ & $1.41 \pm 0.10^{\mathrm{ab}}$ & $1.22 \pm 0.10^{b}$ & $1.28 \pm 0.01^{\mathrm{b}}$ \\
\hline $\operatorname{Mg}\left(\mathrm{mg} \mathrm{g}^{-1}\right)$ & $0.96 \pm 0.08^{\mathrm{a}}$ & $0.96 \pm 0.01^{\mathrm{ab}}$ & $0.86 \pm 0.01^{\mathrm{ab}}$ & $0.90 \pm 0.09^{a b}$ & $0.74 \pm 0.14^{\mathrm{ab}}$ & $0.75 \pm 0.04^{b}$ \\
\hline $\mathrm{Fe}\left(\mu \mathrm{g} \mathrm{g}^{-1}\right)$ & $8.78 \pm 1.05^{c}$ & $10.5 \pm 0.15^{b c}$ & $11.7 \pm 0.13^{\mathrm{ab}}$ & $11.8 \pm 0.84^{\mathrm{a}}$ & $10.8 \pm 0.29 \mathrm{ab}$ & $12.3 \pm 0.12^{\mathrm{a}}$ \\
\hline $\mathrm{Cu}\left(\mu \mathrm{g} \mathrm{g}^{-1}\right)$ & $0.87 \pm 0.13^{\mathrm{a}}$ & $0.63 \pm 0.03^{b c}$ & $0.74 \pm 0.06^{\mathrm{abc}}$ & $0.77 \pm 0.03^{\mathrm{ab}}$ & $0.57 \pm 0.05^{\mathrm{c}}$ & $0.79 \pm 0.02^{\mathrm{ab}}$ \\
\hline $\operatorname{Mn}\left(\mu g g^{-1}\right)$ & $5.51 \pm 0.48^{c}$ & $6.00 \pm 0.06^{b c}$ & $7.01 \pm 0.03^{\mathrm{a}}$ & $6.82 \pm 0.04^{\mathrm{a}}$ & $5.61 \pm 0.01^{c}$ & $6.54 \pm 0.07^{a b}$ \\
\hline $\mathrm{Zn}\left(\mu \mathrm{g} \mathrm{g}^{-1}\right)$ & $2.51 \pm 0.14^{\mathrm{a}}$ & $2.70 \pm 0.29^{a}$ & $1.40 \pm 0.15^{b c}$ & $1.56 \pm 0.17^{b c}$ & $1.36 \pm 0.04^{c}$ & $1.86 \pm 0.02^{b}$ \\
\hline $\mathrm{Ni}\left(\mu \mathrm{g} \mathrm{g}^{-1}\right)$ & $0.22 \pm 0.05^{\mathrm{a}}$ & $0.23 \pm 0.03^{a}$ & $0.26 \pm 0.05^{\mathrm{a}}$ & $0.18 \pm 0.01^{b}$ & nd & nd \\
\hline $\mathrm{Cr}\left(\mu \mathrm{g} \mathrm{g}^{-1}\right)$ & $0.07 \pm 0.02^{\mathrm{a}}$ & $0.05 \pm 0.01^{\mathrm{a}}$ & $0.06 \pm 0.01^{\mathrm{a}}$ & $0.06 \pm 0.01^{\mathrm{a}}$ & nd & $0.05 \pm 0.01^{\mathrm{a}}$ \\
\hline \multicolumn{7}{|c|}{ Mesembryanthemum nodiflorum } \\
\hline $\mathrm{Na}\left(\mathrm{mg} \mathrm{g}^{-1}\right)$ & $6.46 \pm 2.13^{b}$ & $7.92 \pm 3.30 \mathrm{ab}$ & $8.67 \pm 1.70^{\mathrm{ab}}$ & $9.81 \pm 0.23^{\mathrm{ab}}$ & $9.95 \pm 1.80^{\mathrm{ab}}$ & $13.4 \pm 1.3^{\mathrm{a}}$ \\
\hline $\mathrm{K}\left(\mathrm{mg} \mathrm{g}^{-1}\right)$ & $1.42 \pm 0.12^{c}$ & $2.93 \pm 1.70^{\mathrm{a}}$ & $1.93 \pm 0.9^{\mathrm{ab}}$ & $2.03 \pm 0.17^{b}$ & $0.97 \pm 0.07^{\mathrm{c}}$ & $2.00 \pm 0.46^{\mathrm{ab}}$ \\
\hline $\mathrm{Ca}\left(\mathrm{mg} \mathrm{g}^{-1}\right)$ & $0.16 \pm 0.01^{\mathrm{a}}$ & $0.27 \pm 0.25^{\mathrm{a}}$ & $0.34 \pm 0.04^{\mathrm{a}}$ & $0.41 \pm 0.12^{\mathrm{a}}$ & $0.27 \pm 0.24^{\mathrm{a}}$ & $0.33 \pm 0.4^{\mathrm{a}}$ \\
\hline $\operatorname{Mg}\left(\mathrm{mg} \mathrm{g}^{-1}\right)$ & $0.15 \pm 0.02^{c}$ & $0.14 \pm 0.01^{\mathrm{c}}$ & $0.24 \pm 0.02^{\mathrm{a}}$ & $0.20 \pm 0.01^{b}$ & $0.16 \pm 0.01^{c}$ & $0.16 \pm 0.01^{\mathrm{c}}$ \\
\hline $\mathrm{Fe}\left(\mu \mathrm{g} \mathrm{g}^{-1}\right)$ & $1.08 \pm 0.03^{\mathrm{b}}$ & $1.44 \pm 0.50 \mathrm{ab}$ & $1.82 \pm 0.11^{\mathrm{ab}}$ & $1.75 \pm 0.22 \mathrm{ab}$ & $1.10 \pm 0.26^{\mathrm{b}}$ & $1.96 \pm 0.32^{\mathrm{a}}$ \\
\hline $\mathrm{Cu}\left(\mu \mathrm{g} \mathrm{g}^{-1}\right)$ & $1.89 \pm 0.03^{\mathrm{a}}$ & $0.88 \pm 0.02^{c}$ & $0.94 \pm 0.01^{\mathrm{c}}$ & $0.85 \pm 0.04^{\mathrm{c}}$ & $1.25 \pm 0.20^{b}$ & $1.03 \pm 0.12 b c$ \\
\hline $\operatorname{Mn}\left(\mu g g^{-1}\right)$ & $5.30 \pm 0.52^{c}$ & $7.50 \pm 1.19^{b}$ & $8.90 \pm 0.41^{a b}$ & $8.12 \pm 0.42^{b}$ & $5.19 \pm 0.34^{c}$ & $10.1 \pm 1.1^{\mathrm{a}}$ \\
\hline $\mathrm{Zn}\left(\mu \mathrm{g} \mathrm{g}^{-1}\right)$ & $5.61 \pm 0.02^{f}$ & $8.87 \pm 0.37^{\mathrm{e}}$ & $19.4 \pm 0.1^{\mathrm{c}}$ & $58.4 \pm 0.1^{\mathrm{a}}$ & $10.8 \pm 0.3^{\mathrm{d}}$ & $43.0 \pm 1.1^{b}$ \\
\hline $\mathrm{Ni}\left(\mu \mathrm{g} \mathrm{g}^{-1}\right)$ & $0.31 \pm 0.02^{a b}$ & $0.37 \pm 0.04^{\mathrm{a}}$ & $0.15 \pm 0.01^{c}$ & $0.16 \pm 0.1^{\mathrm{c}}$ & $0.15 \pm 0.05^{c}$ & $0.29 \pm 0.03^{b}$ \\
\hline $\mathrm{Cr}\left(\mu \mathrm{g} \mathrm{g}^{-1}\right)$ & $1.63 \pm 0.53^{\mathrm{a}}$ & $1.06 \pm 0.36^{\mathrm{ab}}$ & $0.13 \pm 0.04^{c}$ & $0.17 \pm 0.02^{\mathrm{c}}$ & $0.60 \pm 0.22^{b c}$ & $0.69 \pm 0.25^{b c}$ \\
\hline $\mathrm{Pb}\left(\mu \mathrm{g} \mathrm{g}^{-1}\right)$ & $0.12 \pm 0.01^{b}$ & $0.11 \pm 0.01^{\mathrm{b}}$ & $0.20 \pm 0.02^{\mathrm{a}}$ & $0.21 \pm 0.02^{\mathrm{a}}$ & $0.12 \pm 0.01^{b}$ & $0.20 \pm 0.01^{\mathrm{a}}$ \\
\hline \multicolumn{7}{|l|}{$\mathrm{Na}: \mathrm{K}$ ratio } \\
\hline I. crithmoides & 2.26 & 2.85 & 4.70 & 4.85 & 5.13 & 5.37 \\
\hline M. nodiflorum & 4.54 & 2.70 & 4.49 & 4.83 & 10.2 & 6.7 \\
\hline
\end{tabular}

Limits of detection (LOD): $\mathrm{Cr}-0.01 \mu \mathrm{g} \mathrm{L} \mathrm{L}^{-1}, \mathrm{Ni}-0.02 \mu \mathrm{g} \mathrm{L}{ }^{-1}, \mathrm{~Pb}-0.01 \mu \mathrm{g} \mathrm{L}{ }^{-1}$; In each row, different letters indicate significant differences $(p<0.05)$.

The content of Fe in I. crithmoides increased from 8.78 to $12.3 \mu \mathrm{g} \mathrm{g}^{-1}$ in plants grown at the highest salinity $\left(465 \mathrm{mmol} \mathrm{L}^{-1}\right)$. From a nutritional point of view, this sample

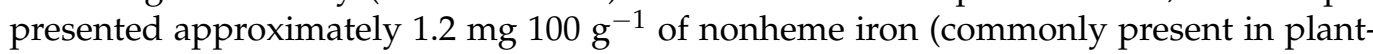
based foods). This result reveals that this halophyte may be a good source of $\mathrm{Fe}$, when compared to the $2.35 \mathrm{mg} 100 \mathrm{~g}^{-1}$ present in spinach, a vegetable commonly seen as a good Fe source [34]. M. nodiflorum proved to be a suitable source of Mn, accumulating this mineral as saline stress increased, doubling the content of this element, from 5.31 to $10.1 \mathrm{\mu g} \mathrm{g}^{-1}$ when comparing plants cultivated at 35 and $465 \mathrm{mmol} \mathrm{L}^{-1}$, respectively. The presence of these and other essential minerals adds nutritional value to these plants as these are indispensable for the maintenance of certain biochemical and physiological processes in the human body [24,32]. M. nodiflorum grown at salinities of 200, 275, and $465 \mathrm{mmol} \mathrm{L}^{-1}$ accumulated $\mathrm{Zn}$ at concentrations of $19.4,58.4,43.0 \mu \mathrm{g} \mathrm{g}^{-1}$, respectively. These values were significantly higher than those found for I. crithmoides, in the present study, or for other halophytes subjected to salt stress, such as Atriplex halimus, Salicornia fruticosa, S. ramosissima, and Cakile maritime $[13,20]$. This accumulation capacity of $\mathrm{Zn}$ has been reported for several plant species of the families Brassicaceae, Caryophyllaceae, and Dichapetalaceae [35]. Furthermore, it is known that greenhouse cultivation favors high mineral absorption [36], and in this case, the combination of greenhouse cultivation and the natural ability of the species to uptake this element can influence $\mathrm{Zn}$ accumulation. 
From a food security perspective, the concentrations of toxic metals were generally low, with $\mathrm{Pb}$ for $\mathrm{M}$. nodiflorum showing concentrations below the limit established by legislation, $0.30 \mu \mathrm{g} \mathrm{g}^{-1}$ [37], and Cd was not detected in either species (LOD: $0.02 \mu \mathrm{g} \mathrm{L}^{-1}$ ).

\subsection{Vitamins and Carotenoids Content}

Vitamin and carotenoid contents of the studied plants are shown in Figure 2. In general, vitamin and carotenoid levels were species-dependent as I. crithmoides presented almost three and four times more vitamin B1 and lutein, respectively, regardless of the salinity, when compared with those of $M$. nodiflorum. Concerning $\beta$-carotene, the content of this carotenoid was higher in I. crithmoides with a trend toward higher concentrations as the salinity increased. Vitamin B6 displayed similar contents in both species. In M. nodiflorum, vitamin $B 1$ tended to increase with salinity, unlike vitamin B6, whose contents remained stable. In I. crithmoides the content of these vitamins did not change with the salinity of the cultivation media. In plants, vitamin B1 is considered a growth factor and is distributed between organs, such as leaves, flowers, fruits, seeds and in certain plant's roots.

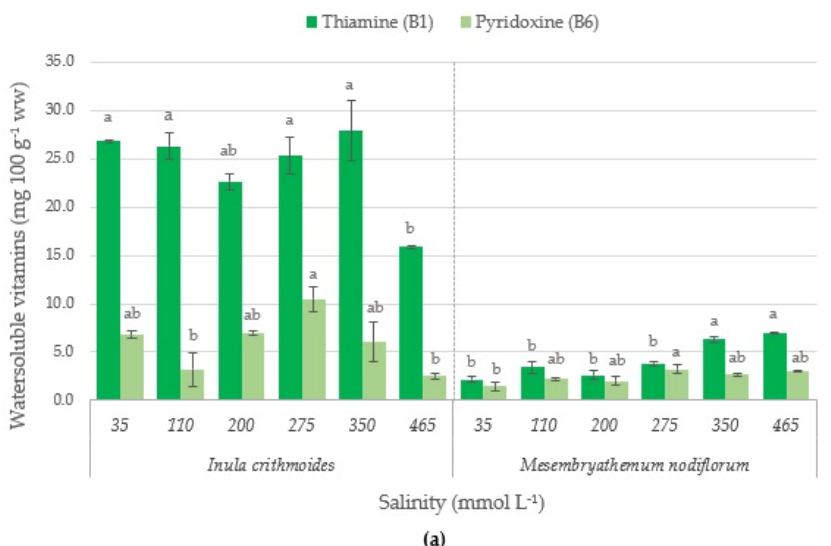

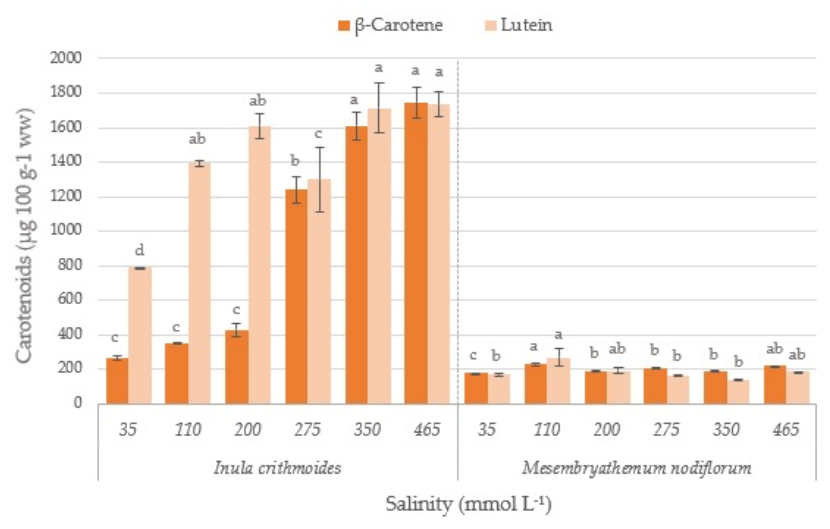

(b)

Figure 2. (a) Vitamin content and (b) carotenoid content of I. crithmoides and M. nodiflorum cultivated at six different salinities. LOD: B1-2.6 $\mu \mathrm{g} \mathrm{mL}^{-1}$, B6-2.1 $\mu \mathrm{g} \mathrm{mL}^{-1}, \beta$-Carotene-8.2 $\mu \mathrm{g} \mathrm{mL}^{-1}$, Lutein-1.4 $\mu \mathrm{g} \mathrm{mL}^{-1}$. In each chart, bars of the same color and labeled with different letters are significantly different $(p<0.05)$.

Vitamin B1 is a coenzyme in metabolic pathways involved in energy production, carbon assimilation and respiration [38]. It has also been demonstrated that vitamin B1 is an important component in plant stress responses [39]. The values obtained are in accordance with Chamkouri et al. [40], which reported 181 and $102 \mathrm{mg} \mathrm{Kg}^{-1}$ dry weight (dw), respectively, in leaves of Suaeda aegyptiaca and Suaeda vera. These values were also comparable to those found in vegetables naturally rich in this vitamin, such as garlic [34]. Considering that the recommended daily dose (RDD) for this vitamin is $2 \mathrm{mg}$, the consumption of $20 \mathrm{~g}$ of these plants (the estimated dose in a salad or as an ingredient in another dish) will represent $50 \%$ and $20 \%$ of the DDR for I. crithmoides and M. nodiflorum, respectively. According to Regulation (EC) No. 1924/2006 of the European Parliament and of the Council of 20 December 2006 on nutrition and health claims made on foods, a claim that a food is a 'source of' vitamins is justified when $100 \mathrm{~g}(\mathrm{ww})$ of the product contains at least 15\% of the RDD (as defined in the Annex to Directive 90/496/EEC). However, a claim that a food is "rich in" vitamins, is made if it contains at least twice the content required for the "source of" claim. Thus, I. crithmoides and M. nodiflorum can also be considered plants rich in vitamin B6.

The carotenoid content in I. crithmoides increased with increasing salinity in the nutrient solution. The values presented in this study are in accordance with the values obtained in a study conducted in Inula helenium L. [41], which were respectively, 19 and $16 \mu \mathrm{g} \mathrm{g}^{-1}$ ww for $\beta$-carotene and lutein, representing more than $72 \%$ of the total carotenoids content. Similar values of $\beta$-carotene can be found in endives or arugula [34], which are generally 
considered good sources of vitamin A, since $\beta$-carotene is metabolized into this vitamin in animal tissues. Lutein is an important pigment for the regeneration and prevention of aging-associated macular degeneration. It is found in foods such as spinach, in relatively high concentrations of $12 \mathrm{mg} 100 \mathrm{~g} \mathrm{~g}^{-1} \mathrm{ww}$ [34]. The analyzed plants have lower concentrations than spinach but are much higher than those found in other halophyte plants, such as Prosopis strombulifera, Sesuvium portulacastrum or Tecticornia indica [42,43].

\subsection{Antioxidant Activity}

Halophyte extracts, including extracts of the Inula crithmoides and Mesembryanthemum nodiflorum show a moderate phenolic content, abundant interspecific variability for free radical scavenging capacity, and may work as superoxide anion inhibitors [2,44].

In this study, two phenolic groups were evaluated in the acetone extracts of the plants: total phenolic compounds and condensed tannins. The evaluation of total phenolics was performed by testing the reagent Folin-Ciocalteu (F-C reagent), measured as mg GAE (Gallic acid equivalent) per mg of sample, and the condensed tannins assay evaluated the changes caused by salt stress in the content of proanthocyanidins. The results are shown in Table 3.

Table 3. Total phenolics contents (TPC; $\mathrm{mg} \mathrm{GAE}^{-1} \mathrm{dw}$ ), condensed tannin content (CTC; $\mathrm{mg} \mathrm{CE} \mathrm{g}^{-1} \mathrm{dw}$ ), and antioxidant activity-radical scavenging ( $\mathrm{IC}_{50} \mathrm{mg} \mathrm{mL}^{-1}$ of extract) of I. crithmoides and M. nodiflorum cultivated at six different salinities.

\begin{tabular}{|c|c|c|c|c|c|c|}
\hline Salinity $\left(\mathrm{mmol} \mathrm{L}^{-1}\right)$ & 35 & 110 & 200 & 275 & 350 & 465 \\
\hline \multicolumn{7}{|l|}{ Inula crithmoides } \\
\hline TPC & $16.5 \pm 3.3^{\mathrm{a}}$ & $10.5 \pm 1.9^{b}$ & $7.04 \pm 0.50^{b}$ & $7.85 \pm 0.84^{b}$ & $7.39 \pm 0.90^{b}$ & $9.06 \pm 0.77^{b}$ \\
\hline СТC & $42.5 \pm 1.8^{\mathrm{ab}}$ & $45.8 \pm 2.5^{\mathrm{a}}$ & $28.6 \pm 2.0^{\mathrm{d}}$ & $33.5 \pm 2.6^{\mathrm{cd}}$ & $34.8 \pm 0.8^{\mathrm{c}}$ & $37.2 \pm 0.5^{b c}$ \\
\hline \multicolumn{7}{|c|}{ Radical Scavenging Activity } \\
\hline ABTS & $9.20 \pm 0.09^{\mathrm{a}}$ & $6.12 \pm 0.28^{b}$ & $8.18 \pm 0.98^{a}$ & $>10$ & $9.10 \pm 0.59^{\mathrm{a}}$ & $>10$ \\
\hline DPPH & $5.04 \pm 0.43^{\mathrm{a}}$ & $3.89 \pm 0.37^{b}$ & $3.96 \pm 0.29 \mathrm{~b}$ & $3.88 \pm 0.13^{b}$ & $3.59 \pm 0.27^{b}$ & $3.40 \pm 0.48^{b}$ \\
\hline \multicolumn{7}{|c|}{ Mesembryanthemum nodiflorum } \\
\hline TPC & $2.90 \pm 0.77^{b c}$ & $2.24 \pm 1.15^{\mathrm{c}}$ & $3.77 \pm 1.73^{\mathrm{ab}}$ & $4.39 \pm 1.35^{\mathrm{a}}$ & $2.09 \pm 0.2^{c}$ & $2.16 \pm 0.12^{\mathrm{c}}$ \\
\hline СТC & $18.6 \pm 1.1^{b}$ & $17.3 \pm 0.6^{\mathrm{c}}$ & $22.6 \pm 0.8^{a}$ & $18.0 \pm 0.7 \mathrm{bc}$ & $18.1 \pm 1.2^{b c}$ & $14.2 \pm 0.6^{\mathrm{d}}$ \\
\hline \multicolumn{7}{|c|}{ Radical Scavenging Activity } \\
\hline ABTS & $6.65 \pm 0.01^{\mathrm{a}}$ & $6.58 \pm 0.01^{\mathrm{a}}$ & $3.46 \pm 0.16^{c}$ & $2.02 \pm 0.05^{\mathrm{d}}$ & $4.19 \pm 0.31^{\mathrm{b}}$ & $3.18 \pm 0.02^{\mathrm{c}}$ \\
\hline $\mathrm{DPPH}$ & $4.56 \pm 0.50^{\mathrm{a}}$ & $4.81 \pm 1.74^{\mathrm{a}}$ & $3.73 \pm 0.53^{\mathrm{ab}}$ & $2.75 \pm 0.58^{b}$ & $3.77 \pm 0.83^{\mathrm{ab}}$ & $3.54 \pm 0.09 \mathrm{ab}$ \\
\hline
\end{tabular}

ABTS-2,2'-azino-bis(3-ethylbenzothiazoline-6-sulfonic acid); DPPH-1,1-diphenyl-2-picrylhydrazyl radical. In each row, different letters represent significant differences $(p<0.05)$. The $\mathrm{IC}_{50}\left(\mathrm{mg} \mathrm{mL}^{-1}\right)$ of positive controls were as follows: ABTS (BHT-0.14); DPPH (BHT-0.11).

I. crithmoides extracts proved to be susceptible to the loss of the production capacity of phenolic compounds with the increase of the salt stress, presenting a sharp drop at salinities of $100 \mathrm{mmol} \mathrm{L}^{-1}$ or higher. This behavior corroborates with Alhdad et al. [45], who stated that the production of phenolics can be induced by several forms of abiotic stress, under which saline stress can promote both the reduction and accumulation of these compounds. Conversely, M. nodiflorum extracts showed an increase trend in phenolics up to a salinity of $275 \mathrm{mmol} \mathrm{L}^{-1}$, followed by a decrease in these values for higher salinities (350 and $465 \mathrm{mmol} \mathrm{L}^{-1}$ of $\mathrm{NaCl}$ ). Similar responses were observed in other halophyte species, such as S. ramosissima, Atriplex prostrata, and Desmostachya bipinnata, subjected to salt stress $[20,46,47]$. Such responses can be attributed to the need for resource management by the plants upon exposure to high salt concentrations. Reduced ability to produce phenolic compounds may be a consequence of the need for using the energy available to promote salt exclusion or osmolyte biosynthesis [48]. Care should be taken when considering these results as the F-C reagent can react with other compounds also present in the plants, such as vitamin $C$ and proteins $[49,50]$. In this study, however, protein content showed an opposite trend to TPC, and such interference may have been minimum.

Previous research has confirmed that phenolic compounds have an important activity as antioxidant agents in halophytes. According to Falleh et al. [44], these antioxidants work as protective agents against stress, which may include the elimination of large amounts of 
reactive oxygen species (ROS) from cells. This antioxidant capacity can be assessed with the ABTS and DPPH assays that measure the ability of the plant extracts to scavenge free radicals. Usually, a positive relationship is observed between the phenolic compounds content of the extracts and their antioxidant activity. The ABTS assay is recommended for both hydrophilic and lipophilic compounds, while the DPPH method presents better results for compounds soluble in organic solvents [51]. However, both have been widely used due to the high sensitivity in identifying antioxidant compounds at low concentrations.

In Table 3, it is possible to verify that the I. crithmoides extracts showed lower capacity to sequester the radical $\mathrm{ABTS}^{+} \bullet$, compared to those of $M$. nodiflorum, with values close to or higher than $10 \mathrm{mg} / \mathrm{mL}$ (the highest concentration of extract tested). The best result was observed for plants grown at a salinity of $110 \mathrm{mmol} \mathrm{L}^{-1}$, resulting in an $\mathrm{IC}_{50}$ of $6.12 \pm 0.28 \mathrm{mg} \mathrm{mL}^{-1}$. However, for $M$. nodiflorum extracts, a continuous significant increase in the antioxidant capacity with salt stress was observed up to a salinity of $275 \mathrm{mmol} \mathrm{L}^{-1}$, where the lowest $\mathrm{IC}_{50}$ for the $\mathrm{ABTS}^{+} \bullet$ radical, $2.02 \pm 0.05 \mathrm{mg} \mathrm{mL}^{-1}$, was obtained (Table 3). Although low, when compared with the positive control (BHT; $\mathrm{IC}_{50}$ $0.07 \mathrm{mg} \mathrm{mL}^{-1}$ ), all extracts had the ability to sequester the DPPH radical. Both species showed increased antioxidant capacity with higher salinities, observable from 100 and $275 \mathrm{mmol} \mathrm{L}^{-1}$ upward for I. crithmoides and M. nodiflorum extracts, respectively, similar to what was observed for the $\mathrm{ABTS}^{+} \bullet$ radical (Table 3). Contrary to what was reported by Doudach et al. [52], who reported a positive relationship between tannins content and other phytoactive compounds concerning the antioxidant capacity of halophyte extracts, no correlation between phenolics or tannins contents and the antioxidant activity was found in this study. Although it is widely accepted that higher phenolic compounds lead to higher antioxidant capacity, studies have not identified any relationship between the concentration of phenolic extracts and increased ability to scavenge free radicals, such as $\mathrm{ABTS}^{+} \bullet$ and DPPH• in extracts of other halophytes $[10,20]$. In this perspective, the presence of other antioxidant compounds in halophyte plants, such as vitamins and carotenoid pigments, can be related to changes in the antioxidant capacity of these extracts [53]. Furthermore, from the nutritional point of view, the presence of bioactive compounds and the possibility of improving the capacity of halophytes to produce these compounds through controlled and sustainable cultivation causes these plants to be good candidates for using them as functional food and in biomedical applications.

\subsection{Sensory Properties}

The commercial aspect motivated the evaluation of these plants regarding their organoleptic characteristics. For this, a panel of fine-dining chefs as culinary experts, most awarded with Michelin stars, was assembled. The evaluation was based on the QDA test, and the chefs' panel was responsible for the definition of the sensory attributes to better evaluate the plants, aiming for the product with the best sensory features. Each chef received a set of plants cultivated at different salinities and completed a form with their evaluation of the several parameters, including salty and bitter taste, crunchiness, juiciness, presence of fibers (fibrosity), appearance, and plant length. The answers were ranked, and the results for both species are shown in Figure 3.

Overall, despite a wide range between the lowest and highest cultivation salinity of the samples (35-465 $\mathrm{mmol} \mathrm{L}^{-1}$ ), little differences in sensory characteristics were observed. However, for both species, samples grown at $350 \mathrm{mmol} \mathrm{L}^{-1}$ (orange line), were better evaluated in the overall assessment.

Halophytes are naturally salty plants and, in this sense, the preference of the panel for a sample saltier than usual can be explained by neuroscience. According to Leshem [54], the human appetite for salt is multifactorial in origin and is expressed habitually and unconsciously, and although we do not prefer eating a spoonful of pure salt, we are usually attracted to salty foods, a will generically defined as "sodium appetite". 


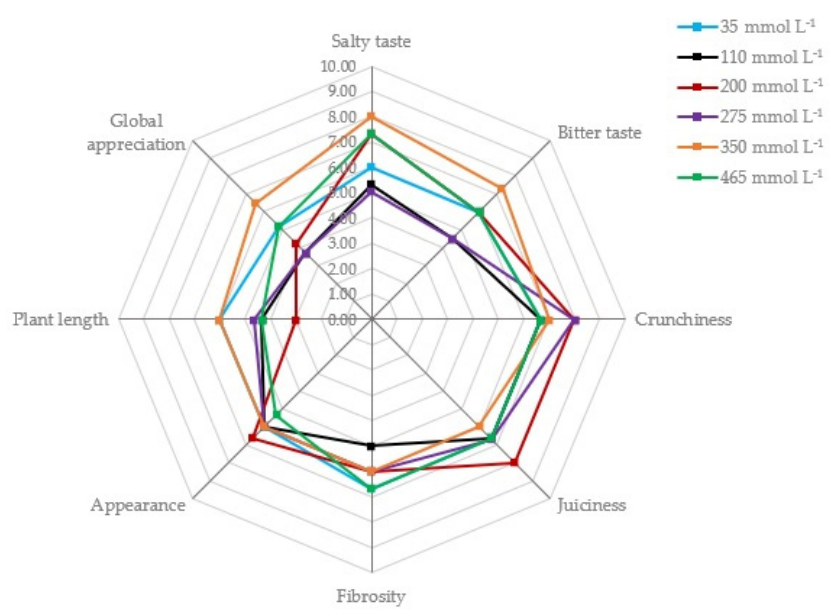

(a)

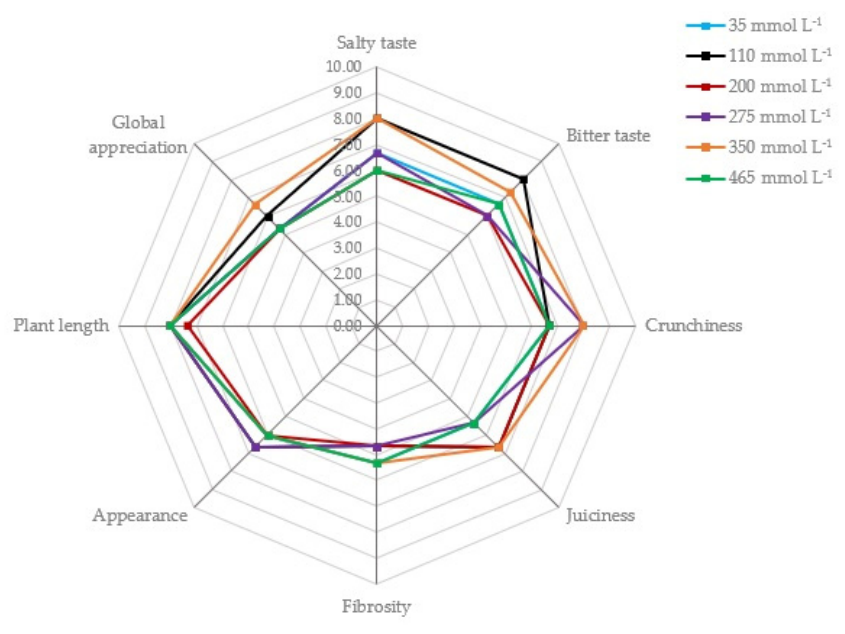

(b)

Figure 3. Visual display of the sensory attributes based on the results of the QDA test for I. crithmoides (a) and M. nodiflorum (b) cultivated at six different salinities. For each attribute, the ranking increases as it moves farther away from the central point.

The most obvious effect of reducing $\mathrm{NaCl}$ in the culture of the samples was to reduce the salty taste; however, other effects were also observed. Plants grown at $35 \mathrm{mmol} \mathrm{L}^{-1}$ had a significantly higher moisture content than samples grown at $465 \mathrm{mmol} \mathrm{L}^{-1}$. This may be due to the liquid retention capacity promoted by the increase in $\mathrm{NaCl}$ content [55]. Moreover, according to Gaudette and Piestrasik [56], lower $\mathrm{NaCl}$ levels can enhance bitterness, decrease positive flavors associated with salinity, and affect the appearance of the food, such as color and texture (significant reduction observed in both species as shown in Table 1). It can also explain why the sample of I. crithmoides cultivated at $350 \mathrm{mmol} \mathrm{L}^{-1}$ received a better evaluation for the attributes of salty taste, bitter taste, plant length, and global appreciation, whereas $M$. nodiflorum scored better regarding its salty taste, crunchiness, juiciness, fibrosity, and plant length.

Despite the several recent studies with halophyte species for human consumption, few focus their interests on the sensory analysis of these plants. Until now, for the species evaluated in this study cultivated under controlled conditions, we are not aware of any published study on sensory properties, making these results a valuable literary source.

\subsection{Multivariate Analysis}

To assess the relationships between the different parameters studied and how they were globally influenced by the imposed saline stress, a principal component analysis (PCA) was performed. With PCA, it is possible to visualize the information contained in the various original variables into a smaller set of statistical variables (components) with the minimum loss of information [57]. The analysis was performed separately for each species because the differences between their composition overlapped their response to salinity stress, thus hampering the visualization of such differences. The results are shown in Figure 4.

For I. crithmoides, (Figure 4a) the first two principal components explained $67.67 \%$ of the total variation of the data (PC1 45.97\%; PC2 21.70\%), and for M. nodiflorum (Figure 4b), explained 58.59\% (PC1 35.95\%; PC2 22.64\%). In the loadings scatter plot of the I. crithmoides variables (Figure 4a), the parameters of relative productivity, texture, moisture, fat, TDF, K, $\mathrm{Ca}, \mathrm{Mg}, \mathrm{Cu}, \mathrm{Zn}, \mathrm{Ni}, \mathrm{Cr}, \mathrm{Pb}, \mathrm{B} 1$, lutein, TPC, CTC, ABTS, and global appreciation were the most discriminant. Certain parameters exhibited significant correlations $(p<0.05)$ with the conductivity of the samples, a parameter that can be used as a proxy for the salinity of the cultivation media. These were: moisture $(-0.9487)$, protein $(0.8928), \mathrm{Na}(0.9735)$, $\mathrm{K}(-0.8753), \mathrm{Ca}(-0.9334), \mathrm{Mg}(-0.8312), \mathrm{Fe}(0.9054), \mathrm{Zn}(-0.8149)$, lutein (0.9163), TPC $(-0.9106)$, and DPPH (-0.9072). For M. nodiflorum (Figure $4 \mathrm{~b})$, the most discriminant 
parameters in PC1 were relative productivity, texture, moisture, protein, lipids, $\mathrm{Cu}, \mathrm{Ni}, \mathrm{Cr}$, lutein, CTC, ABTS, DPPH, salty taste, bitter taste, juiciness, and appearance, several of which also present significant correlations $(p<0.05)$ with conductivity: $\mathrm{Na}(0.8801)$, vit B6 (0.8828), and ABTS (-0.8580). Parameters showing positive correlation with conductivity indicate that plants have improved contents with increasing salinities, further indicating that, in this species, these components can be boosted by the application of moderate abiotic stress such as a culture solution with high salinity. However, as lower $\mathrm{IC}_{50}$ values for ABTS and DPPH represent higher antioxidant capacity, a negative relationship with conductivity indicates that these defenses may have been induced by salinity stress.

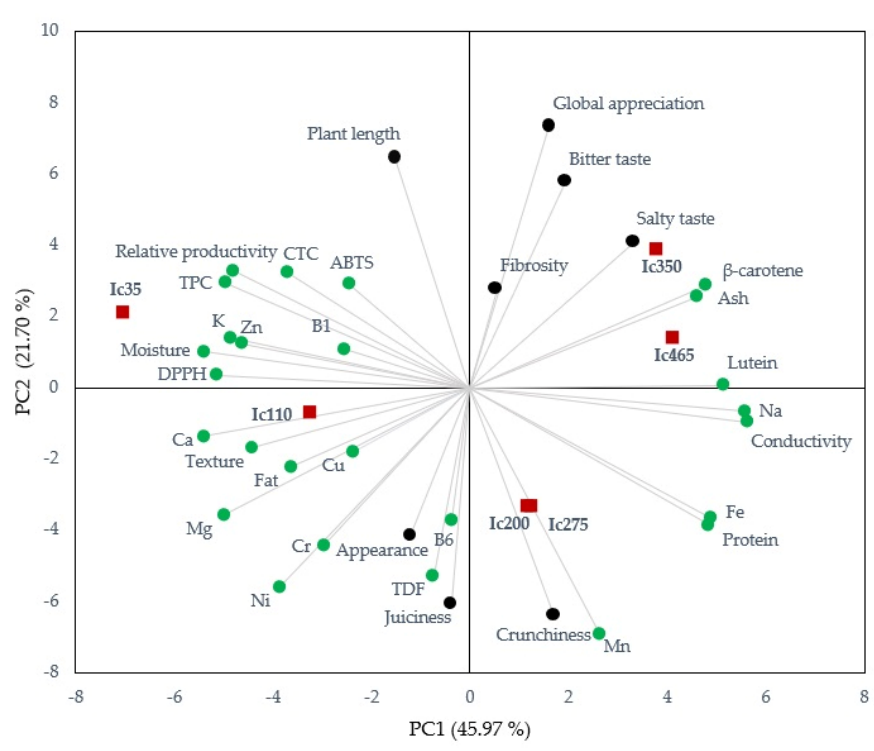

(a)

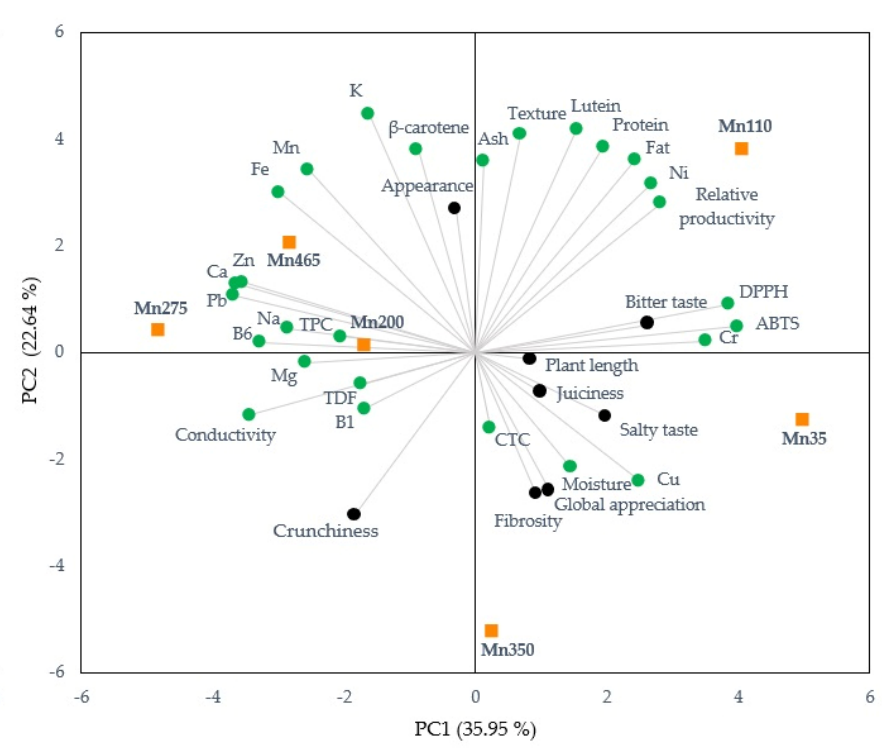

(b)

Figure 4. Principal components analysis biplot showing the loadings on PC1 and PC2 of the different parameters of the nutritional profile (green circles), organoleptic characteristics ranking (black circles), and data scores of I. crithmoides (a) and M. nodiflorum (b) grown under different salinities (red and orange squares).

The red and orange squares, respectively in Figure $4 a, b$, show the data scores of the samples (plants grown at different salinities) for I. crithmoides and M. nodiflorum. For I. crithmoides, their placement along PC1 (the most representative axis) shows a clear distinction between plants cultivated at the lowest salinities $\left(35\right.$ and $\left.110 \mathrm{mmol} \mathrm{L}^{-1}\right)$ and those cultivated at higher salt concentrations, however for M. nodiflorum, this behavior is not as evident. It also shows the better functional profile and organoleptic evaluation of the plants cultivated at salinities $\geq 275 \mathrm{mmol} \mathrm{L}^{-1}$, as most of the organoleptic variables (black circles in Figure 4) for both species are positioned in the same quadrant as the $350 \mathrm{mmol} \mathrm{L}^{-1}$ data scores, although for $M$. nodiflorum the lowest salinity $\left(35 \mathrm{mmol} \mathrm{L}^{-1}\right)$ is also in this quadrant. The enhanced functional profile of I. crithmoides grown at higher salinities (Figure 4a), is also evident by the placement of Ic350 and Ic465 data scores in the same quadrant as that of the carotenoid pigments and "global appreciation", but in the opposite quadrant of the $\mathrm{IC}_{50}$ of the DPPH and ABTS assays. For M. nodiflorum (Figure $4 \mathrm{~b}$ ), it is apparent the better functional profile of the plants cultivated at 275 and $465 \mathrm{mmol} \mathrm{L}^{-1}$ (Mn275 and Mn465), which were positioned in the same quadrant as that of $\beta$-carotene, and vitamins B1 and B6. Similarly, to I. crithmoides these exist in the opposite quadrant in which the $\mathrm{IC}_{50}$ of the DPPH and ABTS assays are located.

\section{Materials and Methods}

\subsection{Plant Material and Growth Conditions}

The study was conducted in a polyethylene greenhouse of approximately $200 \mathrm{~m}^{2}$ at the facilities of RiaFresh (Portugal) from March to October 2017. I. crithmoides and 
M. nodiflorum were grown in a closed soilless cultivation system. Seeds were sown directly in substrate and placed in honeycombed trays. Seedlings developed under natural photoperiod conditions and air temperature. The two species studied were distributed over six cultivation tables, each corresponding to a specific salinity treatment. Each table contained six trays, randomly distributed, corresponding to three repetitions for each species in which each repetition occupied an area of approximately $0.18 \mathrm{~m}^{2}$.

The nutrient solutions were prepared in tanks of $500 \mathrm{~L}$ of capacity using water from a well located nearby the greenhouse. The composition of the solutions is intellectual property of the company and were nutritionally balanced, containing all essential macroand micronutrients. Additionally, no symptoms of nutritional deficiencies were observed throughout the trial. The solutions were constantly aerated using an air pump and a diffusion system. Plants were irrigated with two daily floods, simulating tides. Six salinity levels were imposed: $35,110,200,275,350$, and $465 \mathrm{mmol} \mathrm{L}^{-1} \mathrm{NaCl}$, using $\mathrm{NaCl}$ as the salinizing agent. The salinity levels were defined considering the range between a semisaline medium $\left(<40 \mathrm{mmol} \mathrm{L}^{-1} \mathrm{NaCl}\right)$ and the salinity of sea water $\left(630 \mathrm{mmol} \mathrm{L}^{-1} \mathrm{NaCl}\right)$. Each salinity level corresponded to an individual tank in which $\mathrm{NaCl}$ was added and dissolved in the nutrient solution.

Monitoring of nutrient solutions was conducted through daily measurements of $\mathrm{pH}$ (Hanna Instruments) and electrical conductivity (EC, $\mathrm{dS} \mathrm{m}^{-1}$, Hanna Instruments), whereas nitrate concentration $\left(\mathrm{NO}_{3}{ }^{-}, \mathrm{mg} \mathrm{L}^{-1}\right)$ was determined twice a week according to Hoather et al. [58]. Briefly, a sample of the nutrient solution was collected and filtered to remove possible interference from suspended particles and acidified with $\mathrm{HCl}(1 \mathrm{M})$, afterward the UV absorption was measured at $220 \mathrm{~nm}$ for the determination of $\mathrm{NO}_{3}{ }^{-}$, and a second measurement at $275 \mathrm{~nm}$ was used to correct the $\mathrm{NO}_{3}{ }^{-}$value. Absorption measurements were performed using a UV-Visible Spectrophotometer (UV-160 A, Shimadzu Kyoto, Japan). During the experiment, the solutions were refilled twice a week and completely replaced at least once a month.

Harvesting was performed when the stems of each species reached at least $20 \mathrm{~cm}$ height. The cuttings were performed using pruning shears and the fresh weight of the collected biomass was determined immediately. The productivity was quantified based on the fresh biomass of the aerial part harvested by area and time after sowing $\left(\mathrm{g} \mathrm{m}^{-2}\right.$ day $\left.^{-1}\right)$. The relative productivity was calculated for each salinity level and expressed as a percentage of variation compared to the lower salinity $\left(35 \mathrm{mmol} \mathrm{L}^{-1}\right)$. A sample of the aboveground biomass from each treatment and from each repetition was collected and transported to the laboratory in a refrigerated bag. Samples were frozen $\left(-20^{\circ} \mathrm{C}\right)$ and later freeze-dried and milled in a planetary ball mill (Retsch-PM 100, Retsch $\mathrm{GmbH}$, Haan, Germany). Powdered samples were kept in a desiccator until the analyses.

\subsection{Nutritional Characterization}

\subsubsection{Proximal Composition}

The fresh biomass was used to determine the moisture content in a forced air circulation oven at $105{ }^{\circ} \mathrm{C}$ for $16 \mathrm{~h}$. To translate the salty flavor of the fresh plants, the samples were macerated with distilled water at a ratio of 1:10 $(w / w)$ and the electric conductivity (EC) measured using a conductivity meter (Hanna Instruments).

The remaining parameters were determined on freeze-dried biomass for $48 \mathrm{~h}$ at $-55{ }^{\circ} \mathrm{C}$ (LyoAlfa 10/15-Telstar, Spain). Total protein content was estimated by the total $\mathrm{N}$ content (conversion factor: 6.25) measured in an Elemental Analyzer model Vario III (Vario EL, Germany). The ash content was determined by incineration at $550 \pm 15^{\circ} \mathrm{C}$ for $6 \mathrm{~h}$ in a muffle furnace (Nabertherm $\mathrm{GmbH}, \mathrm{L} \mathrm{3/12}$ ). Crude fat was determined with the conventional single-phase extraction method [59] with some modifications; briefly, dried biomass was homogenized in chloroform, methanol, and water $(2: 2: 1, w / v / v)$ in an UltraTurrax disperser (IKA-Werke GmbH Staufen, Germany) and the lipidic phase was collected and evaporated in a dry bath. The result was obtained by weight difference. Total dietary fiber (TDF) was determined according to McCleary et al. [60] by an enzymatic-gravimetric 
method, as described in the kit manual provided by Megazyme (Megazyme International Ireland Limited, Bray, Ireland), based on the AACC method 32-05.01 and AOAC method 985.29, and expressed as $\mathrm{g} 100 \mathrm{~g}^{-1} \mathrm{ww}$.

\subsubsection{Firmness}

The firmness was determined as resistance to penetration measured with a texturometer (LFRA Texture Analyzer, Brookfield) equipped with a $1.5 \mathrm{~kg}$ cell. According to the description by Taniwaki et al. [61], each sample was placed between two metal plates with a cylindrical hole in the center $(\varnothing=15 \mathrm{~mm})$ that penetrated until the samples broke. A stainless-steel drilling probe (TA-39) with a diameter of $2 \mathrm{~mm}$ and a length of $20 \mathrm{~mm}$ was used. For each sample, five replicates were performed, and the probe penetration force was measured in grams $(\mathrm{g})$.

\subsection{Minerals}

In triplicate, the ashes of each species were digested with a mixture of $65 \%$ nitric acid $\left(\mathrm{HNO}_{3}\right)$ and hydrogen peroxide $\left(\mathrm{H}_{2} \mathrm{O}_{2}\right)$ 2:1 (v:v) under constant heating until a white homogeneous precipitate was obtained, followed by dilution of the sample in $5 \% \mathrm{HNO}_{3}$. Mineral elements were analyzed using a microwave plasma-atomic emission spectrometer (MP-AES; Agilent 4200 MP-AES, Australia). The blanks values were subtracted to correct the final concentrations of analyzed metals. Results were expressed as $\mathrm{mg}$ or $\mu \mathrm{g} \mathrm{g}^{-1}$ wet weight (ww).

\subsection{Vitamins and Carotenoids}

The extraction of water-soluble vitamins and carotenoids was based on the modified version of Santos et al. [62] and the respective contents were quantified by HPLC-DAD using the method proposed by Klejdus et al. [63]. The procedure was described in detail in a previous study [20]. In brief, $0.25 \mathrm{~g}$ of freeze-dried powder were extracted with ammonium acetate $\left(10 \mathrm{mmol} \mathrm{L}^{-1}\right)$ and a methanol solution $(50: 50 \mathrm{v} / \mathrm{v})$ containing $0.01 \%$ of butylated hydroxytoluene (BHT) to prevent oxidation. Hippuric acid $\left(2.5 \mu \mathrm{g} \mathrm{mL}{ }^{-1}\right)$ was added as an internal standard. Samples were homogenized and sonicated in an ultrasound bath and then centrifuged at 12,500 $\mathrm{g}$ for $20 \mathrm{~min}$. The supernatant containing the watersoluble vitamins was placed under a gentle nitrogen stream to evaporate the methanol, the final volume was registered, and the samples were filtered through a $0.22 \mu$ m nylon filter membrane and stored at $-80^{\circ} \mathrm{C}$ until analysis. For the carotenoid content, the pellet was extracted twice with ethyl acetate, the supernatants combined, dried, resuspended in $1 \mathrm{~mL}$ of HPLC grade ethyl acetate, filtered through a $0.22 \mu \mathrm{m}$ PTFE filter, and stored at $-80{ }^{\circ} \mathrm{C}$ until analysis.

Quantification was performed in a Dionex HPLC Analytical System (Sunnyvale, CA, USA) equipped with a photodiode array detector and fitted with an automated sample injector. The chromatographic separation was achieved using a Purospher ${ }^{\circledR}$ STAR RP-18 endcapped (Merck) $(250 \times 2.1 \mathrm{~mm}, 5 \mu \mathrm{m})$ column. For the water-soluble vitamins, the column was stabilized at $25^{\circ} \mathrm{C}$ and a $10 \mu \mathrm{L}$ aliquot was injected. A gradient mobile

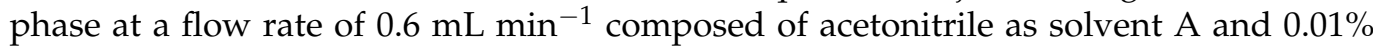
trifluoroacetic acid (TFA) as solvent $B$ was used. The gradient program applied was the following: 0-3 $\min 8 \%$ A; 3-11 $\min 8-98 \%$ A; $11-30 \mathrm{~min} 98 \%$ A. For the carotenoids, the column was stabilized at $20^{\circ} \mathrm{C}$ and a $100 \mu \mathrm{L}$ aliquot was injected. A gradient mobile phase at a flow rate of $1 \mathrm{~mL} \mathrm{~min}^{-1}$ composed of 9:1 $(\mathrm{v} / \mathrm{v})$ acetonitrile and water as solvent $\mathrm{A}$ and ethyl acetate as solvent $\mathrm{B}$. The gradient program was: $0-16 \mathrm{~min}$ from $100 \%$ to $40 \% \mathrm{~A}$; hold for $14 \mathrm{~min}$; 100\% B in $2 \mathrm{~min}$; hold for $3 \mathrm{~min}$; 100\% A in $5 \mathrm{~min}$. The water-soluble vitamins were quantified at a $280 \mathrm{~nm}$ wavelength and the carotenoids at $450 \mathrm{~nm}$. A spectrum between $180 \mathrm{~nm}$ and $800 \mathrm{~nm}$ was recorded to assess peak purity and confirm the identity of the compounds.

Thiamine (B1), pyridoxine (B6), lutein and $\beta$-carotene were obtained from Sigma Aldrich and were of standard quality. Stock standard solutions were prepared in either 
Milli-Q water or methanol (HPLC grade) and standard curves were prepared for each compound. Identification was performed using the retention times compared to those of the pure standard solutions. Quantification was conducted using the peak areas and the final values were expressed in $\mu \mathrm{g}$ (or $\mathrm{mg}$ ) per $100 \mathrm{~g}$ of biomass (ww).

\subsection{Antioxidant Capacity}

For the analyses of antioxidant activity, extracts were prepared from the dried biomass powder with $80 \%$ acetone, as described by Lima et al. [20].

\subsubsection{Radical Scavenging Activity (RSA)}

RSA on ABTS radical was evaluated following the method described by Re et al. [64]. Briefly, in 96-well microplates, the ABTS radical was prepared fresh until an absorbance of approximately 0.7 at $734 \mathrm{~nm}$ was obtained. At a later stage, $10 \mu \mathrm{L}$ of the extract was mixed with $190 \mu \mathrm{L}$ of the ABTS solution. The mixture was incubated for $6 \mathrm{~min}$ in the dark at room temperature (RT) and the absorbance was measured at $734 \mathrm{~nm}$. A solution containing $10 \mu \mathrm{L}$ of extract and ethanol was used as the color control.

RSA on the DPPH radical was evaluated by the method described by Moreno et al. [65]. In 96-well plates, $22 \mu \mathrm{L}$ of the extract was mixed with $200 \mu \mathrm{L}$ of DPPH $120 \mu \mathrm{M}$, previously prepared in methanol. The mixture was incubated at RT for $30 \mathrm{~min}$, and the absorbance was measured at $517 \mathrm{~nm}$. To eliminate any interference from the color of the extracts, a color control was created by mixing $22 \mu \mathrm{L}$ of extract and methanol. In both methods, a positive control with BHT was performed and activity was expressed as percentage relative to a negative control containing DMSO instead of sample. Moreover, for the extracts displaying activity greater than $50 \%$ (at a concentration of $10 \mathrm{mg} \mathrm{mL}^{-1}$ ), the mean inhibitory concentrations $\left(\mathrm{IC}_{50}\right)$ were determined.

\subsubsection{Total Phenolics Content (TPC) and Condensed Tannins Content (CTC)}

The total phenolics (TPC) and condensed tannins contents (CTC) were determined by spectrophotometry. TPC was determined by the Folin-Ciocalteu assay, with modifications [66]. Absorbance was measured at $725 \mathrm{~nm}$ and gallic acid was used as a standard. Results were expressed in gallic acid equivalents per gram of dried extract (mg GAE $\mathrm{g}^{-1} \mathrm{dw}$ ). Tannins content (CTC) was evaluated by the colorimetric method of 4-dimethylaminocinnamaldehyde hydrochloric acid (DMACA-HCl) [67], with the adaptations created by Zou et al. [68] for 96-well microplates. Absorbance was measured at $640 \mathrm{~nm}$ and the results were expressed in milligrams of catechin equivalents per gram of dried extract ( $\mathrm{mg} \mathrm{CE} \mathrm{g}^{-1} \mathrm{dw}$ ). All assays were performed in a microplate reader (Biotek Synergy 4, Biotek Instruments, Winooski, VT, USA).

\subsubsection{Radical Scavenging Activity (RSA)}

RSA on ABTS radical was evaluated following the method described by Re et al. [64]. Briefly, in 96-well microplates, the ABTS radical was prepared fresh until an absorbance of approximately 0.7 to $734 \mathrm{~nm}$ was obtained. At a later stage, $10 \mu \mathrm{L}$ of the extract was mixed with $190 \mu \mathrm{L}$ of the ABTS solution. The mixture was incubated for 6 min in the dark at RT and the absorbance was measured at $734 \mathrm{~nm}$. A solution containing $10 \mu \mathrm{L}$ of extract and ethanol was used as the color control.

RSA on DPPH radical was evaluated by the method described by Moreno et al. [65]. Using 96-well plates, $22 \mu \mathrm{L}$ of the extract was mixed with $200 \mu \mathrm{L}$ of DPPH $120 \mu \mathrm{M}$, previously diluted in methanol. The mixture was incubated at RT for $30 \mathrm{~min}$, and the absorbance was measured at $517 \mathrm{~nm}$. To eliminate any interference from the color of the extracts, a color control was made by mixing $22 \mu \mathrm{L}$ of extract and methanol. In both methods, positive control with BHT was performed and activity was expressed as a percentage relative to a negative control containing DMSO instead of sample. Moreover, for the extracts displaying activity greater than $50 \%$ (at a concentration of $10 \mathrm{mg} \mathrm{mL}^{-1}$ ), the mean inhibitory concentrations $\left(\mathrm{IC}_{50}\right)$ were determined. 


\subsubsection{Total Phenolic Content (TPC) and Condensed Tannin Content (CTC)}

Spectrophotometry was the method used to evaluate the total phenolic content (TPC) and condensed tannin content (CTC). TPC was determined by the Folin-Ciocalteu assay [66], with modifications. Absorbance was measured at $725 \mathrm{~nm}$ and gallic acid was used as a standard. Results were expressed in gallic acid equivalents per gram of dried extract (mg GAE $\mathrm{g}^{-1} \mathrm{dw}$ ). Tannin content (CTC) was evaluated by the colorimetric method of 4-dimethylaminocinnamaldehyde hydrochloric acid (DMACA-HCl) [67], with adaptations created by Zou et al. [68] for 96-well microplates. Absorbance was measured at $640 \mathrm{~nm}$ and the results were expressed in milligrams of catechin equivalents per gram of dried extract $\left(\mathrm{mg} \mathrm{CE} \mathrm{g}^{-1} \mathrm{dw}\right)$. All assays were performed in a microplate reader (Biotek Synergy 4, Biotek Instruments, Winooski, VT, USA).

\subsection{Sensory Analytical Method}

The organoleptic characteristics of the halophyte plants grown in different salinities were evaluated using the quantitative descriptive analysis (QDA) as described by Stone et al. [69], with slight modifications as the place where the tests were performed and the manner the answers were obtained. The experiment started with the choice of attributes, in this case, attributes for flavor (salty and bitter taste), consistency or texture felt in the mouth (crunchiness, juiciness, and fibrosity), and physical (appearance, plant length) characteristics, as well as global appreciation. The intensity of each attribute was measured on an effective scale of four options; for salty and bitter taste, crunchiness, and juiciness characteristics from "not enough" to "too much"; for fibrosity, from "excessive" to "nonexistent"; for plant length, from "too short" to "too long"; and for appearance and global appreciation, from "very bad" to "excellent".

The panel of experts was composed of 10 awarded fine-dining chefs, all with previous knowledge on the use of halophyte plants in gourmet cuisine, and highly experienced in sensory evaluation, fulfilling the requirements of the QDA methodology [70]. All experts were contacted previously to explain the objectives of the sensory evaluation and to engage their commitment. The formulation of the questionnaires was created together with one of the experts to ensure that the language and terminology was clear and accurate. Thus, considering the experience and commitment of the judges, the training and validation stages were considered unnecessary. The samples were therefore shipped to the chefs and the evaluation performed in their respective work environments and answers completed online or sent by mail.

\subsection{Statistical Analysis}

All experiments were performed at least in triplicate and results were expressed as mean \pm standard error of the mean (SEM). Statistical analysis was performed using Statistica 7.0 software (Statsoft Inc., USA), and significant differences were assessed by analysis of variance (ANOVA) using the Tukey HSD (honestly significant differences) test, or the Duncan's new multiple range test when parameterization of the data did not prevail. The $\mathrm{IC}_{50}$ values were calculated by the sigmoidal fitting of the data with the GraphPad Prism v.7.0 software.

Principal components analysis (PCA) was performed for the global data set to assess the interrelationships between variables and obtain a better perception of the different parameters studied using the XLSTAT statistical add-on for excel (Addinsoft Inc, New York, NJ, USA).

\section{Conclusions}

Inula crithmoides and Mesembryanthemum nodiflorum are halophytes that present good adaptation to soilless cultivation systems, a sustainable technique able to produce nutritionally interesting plants, promoting the improvement of essential nutrients for human consumption, such as proteins, minerals, total dietary fiber, and low lipid content. The salinity of the cultivating media significantly improved the nutritional profile, especially 
the antioxidant capacity of the plants and their carotenoid and vitamins contents, but negatively influenced biomass productivity. The salinity of cultivation media was also important for defining the preferred samples in the sensory test, with emphasis on samples grown at $350 \mathrm{mmol} \mathrm{L}^{-1}$ for both species.

Author Contributions: Conceptualization, M.S., J.V. and L.B.; formal analysis, A.R.L., F.G., V.C.-L., C.C., L.M.S., T.S. and R.M.S.C.; funding acquisition, M.S., J.V. and L.B.; methodology, A.R.L., M.S., R.M.S.C. and L.B.; project administration, L.B.; supervision, L.B.; validation, L.B.; writing-original draft, A.R.L. and F.G.; writing-review \& editing, M.S., C.N., J.V. and L.B. All authors have read and agreed to the published version of the manuscript.

Funding: This research was funded by the XtremeGourmet project (ALG-01-0247-FEDER-017676), and projects CCMAR/Multi/04326/2019 and MED/UIDB/05183/2020 funded by FCT-Foundation for Science and Technology and Portuguese National Budget. TS is a FCT doctoral research fellow (SFRH/BD/140143/2018). A. R. Lima acknowledges FCT for grant funding (SFRH/BD/149398/2019).

Informed Consent Statement: Not applicable.

Acknowledgments: The authors want to thank the chefs that participated in the organoleptic evaluation of the plants cultivated under the different salinities, especially to Chef Leonel Pereira (São Gabriel, Almancil, Portugal) that coordinated the chefs selection and participation in the study.

Conflicts of Interest: The authors declare no conflict of interest.

Sample Availability: Samples of the cultivated plants can be supplied by RiaFresh.

\section{References}

1. Flowers, T.J.; Colmer, T.D. Salinity tolerance in halophytes. New Phytol. 2008, 179, 945-963. [CrossRef] [PubMed]

2. Jdey, A.; Falleh, H.; Jannet, S.B.; Hammi, K.M.; Dauvergne, X.; Ksouri, R.; Magné, C. South African Journal of Botany Phytochemical investigation and antioxidant, antibacterial and anti-tyrosinase performances of six medicinal halophytes. S. Afr. J. Bot. 2017, 112, 508-514. [CrossRef]

3. Hanen, F.; Riadh, K.; Samia, O.; Sylvain, G.; Christian, M.; Chedly, A. Interspecific variability of antioxidant activities and phenolic composition in Mesembryanthemum genus. Food Chem. Toxicol. 2009, 47, 2308-2313. [CrossRef] [PubMed]

4. Zurayk, R.A.; Baalbaki, R. Inula crithmoides: A candidate plant for saline agriculture. Arid Soil Res. Rehabil. 1996, 10, 213-223. [CrossRef]

5. Thring, T.S.A.; Weitz, F.M. Medicinal plant use in the Bredasdorp/Elim region of the Southern Overberg in the Western Cape Province of South Africa. J. Ethnopharmacol. 2006, 103, 261-275. [CrossRef] [PubMed]

6. Al Hassan, M.; Estrelles, E.; Soriano, P.; López-Gresa, M.P.; Bellés, J.M.; Boscaiau, M.; Vicente, O. Unraveling Salt Tolerance Mechanisms in Halophytes: A Comparative Study on Four Mediterranean Limonium Species with Different Geographic Distribution Patterns. Front. Plant Sci. 2017, 8, 1-21. [CrossRef]

7. Abdel-wahhab, M.A.; Abdel-azim, S.H.; El-nekeety, A.A. Toxicon Inula crithmoides extract protects against ochratoxin A-induced oxidative stress, clastogenic and mutagenic alterations in male rats. Toxicon 2008, 52, 566-573. [CrossRef]

8. Sassi, A.B.; Bourgougnon, N.; Aouni, M. Natural Product Research: Formerly Natural Product Letters Antiviral activity of some Tunisian medicinal plants against Herpes simplex virus type 1. Nat. Prod. Res. 2008, 22, 37-41.

9. Castañeda-Loaiza, V.; Oliveira, M.; Santos, T.; Schüler, L.; Lima, A.R.; Gama, F.; Salazar, M.; Neng, N.R.; Nogueira, J.M.F.; Varela, J.; et al. Wild vs cultivated halophytes: Nutritional and functional differences. Food Chem. 2020, 333, 127536. [CrossRef]

10. Qasim, M.; Abideen, Z.; Adnan, M.Y.; Gulzar, S.; Gul, B.; Rasheed, M.; Khan, M.A. Antioxidant properties, phenolic composition, bioactive compounds and nutritive value of medicinal halophytes commonly used as herbal teas. S. Afr. J. Bot. 2017, 110, 240-250. [CrossRef]

11. Sambo, P.; Nicoletto, C.; Giro, A.; Pii, Y.; Valentinuzzi, F.; Mimmo, T.; Lugli, P.; Orzer, G.; Mazzetto, F.; Astolfi, S.; et al. Hydroponic Solutions for Soilless Production Systems: Issues and Opportunities in a Smart Agriculture Perspective. Front. Plant Sci. 2019, 10, 923. [CrossRef]

12. Baron, D.; Amaro, A.C.E.; Campos, F.G.; Boaro, C.S.F.; Ferreira, G. Plant Physiological Responses to Nutrient Solution: An Overview. Plant Metab. Regul. Environ. Stress 2018, 415-425. [CrossRef]

13. Agudelo, A.; Carvajal, M.; del Carment Martinez-Bellesta, M. Halophytes of the Mediterranean Basin-Underutilized Species Climate Change. Foods 2021, 10, 119. [CrossRef]

14. Ksouri, R.; Megdiche, W.; Debez, A.; Falleh, H. Salinity effects on polyphenol content and antioxidant activities in leaves of the halophyte Cakile maritima. Plant Physiol. Biochem. 2007, 45, 244-249. [CrossRef] [PubMed]

15. Ventura, Y.; Sagi, M. Halophyte crop cultivation: The case for Salicornia and Sarcocornia. Environ. Exp. Bot. 2013, 92, 144-153. [CrossRef] 
16. Loconsole, D.; Cristiano, G.; De Lucia, B. Glassworts: From wild salt marsh species to sustainable edible crops. Agriculture 2019, 9, 14. [CrossRef]

17. Curadi, M.; Graifenberg, A.; Magnani, G.; Giustiniani, L. Growth and element allocation in tissues of Inula viscosa in sodic-saline conditions: A candidate for programs of desertification control. Arid Land Res. Manag. 2005, 19, 257-265. [CrossRef]

18. Atzori, G.; de Vos, A.C.; van Rijsselberghe, M.; Vignolini, P.; Rozema, J.; Mancuso, S.; van Bodegom, P.M. Effects of increased seawater salinity irrigation on growth and quality of the edible halophyte Mesembryanthemum crystallinum L. under field conditions. Agric. Water Manag. 2017, 187, 37-46. [CrossRef]

19. Aghaleh, M.; Niknam, V.; Ebrahimzadeh, H.; Razavi, K. Salt stress effects on growth, pigments, proteins and lipid peroxidation in Salicornia persica and S. europaea. Biol. Plant. 2009, 53, 243-248. [CrossRef]

20. Lima, A.R.; Castañeda-Loaiza, V.; Salazar, M.; Nunes, C.; Quintas, C.; Gama, F.; Pestana, M.; Correia, P.J.; Santos, T.; Varela, J.; et al. Influence of cultivation salinity in the nutritional composition, antioxidant capacity and microbial quality of Salicornia ramosissima commercially produced in soilless systems. Food Chem. 2020, 333, 127525. [CrossRef]

21. Attia-ismail, S.A. Feeding to Ruminants. In Trace Elements as Contaminants and Nutrients: Consequences in Ecosystems and Human Health; Prasad, M.N.V., Ed.; John Wiley \& Sons, Inc.: Hoboken, NJ, USA, 2008; pp. 701-720. ISBN 9780470180952.

22. Ventura, Y.; Eshel, A.; Pasternak, D.; Sagi, M. The development of halophyte-based agriculture: Past and present. Ann. Bot. 2015, 115, 529-540. [CrossRef] [PubMed]

23. Kumari, A.; Das, P.; Parida, A.K.; Agarwal, P.K. Proteomics, metabolomics, and ionomics perspectives of salinity tolerance in halophytes. Front. Plant Sci. 2015, 6, 1-20. [CrossRef] [PubMed]

24. Wang, J.; Meng, Y.; Li, B.; Ma, X.; Lai, Y.; Si, E.; Yang, K.; Xu, X.; Shang, X.; Wang, H.; et al. Physiological and proteomic analyses of salt stress response in the halophyte Halogeton glomeratus. Plant Cell Environ. 2015, 38, 655-669. [CrossRef]

25. Meng, X.; Zhou, J.; Sui, N. Mechanisms of salt tolerance in halophytes: Current understanding and recent advances. Open Life Sci. 2018, 13, 149-154. [CrossRef] [PubMed]

26. Parihar, P.; Singh, S.; Singh, R.; Singh, V.P.; Prasad, S.M. Effect of salinity stress on plants and its tolerance strategies: A review. Environ. Sci. Pollut. Res. 2015, 22, 4056-4075. [CrossRef]

27. Maciel, E.; Domingues, P.; Domingues, M.R.M.; Calado, R.; Lillebø, A. Halophyte plants from sustainable marine aquaponics are a valuable source of omega-3 polar lipids. Food Chem. 2020, 320, 126560. [CrossRef] [PubMed]

28. Mccleary, B.V. Total dietary fiber (codex definition) in foods and food ingredients by a rapid enzymatic-gravimetric method and liquid chromatography: Collaborative study, first Action 2017.16. J. AOAC Int. 2019, 102, 196-207. [CrossRef]

29. Pastell, H.; Putkonen, T.; Rita, H. Dietary fibre in legumes, seeds, vegetables, fruits and mushrooms: Comparing traditional and semi-automated filtration techniques. J. Food Compos. Anal. 2019, 75, 1-7. [CrossRef]

30. El Shaer, H.M. Halophytes and salt-tolerant plants as potential forage for ruminants in the Near East region. Small Rumin. Res. 2010, 91, 3-12. [CrossRef]

31. Katschnig, D.; Broekman, R. Salt tolerance in the halophyte Salicornia dolichostachya Moss: Growth, morphology and physiology. Environ. Exp. Bot. 2013, 92, 32-42. [CrossRef]

32. Soetan, K.O.; Olaiya, C.O.; Oyewole, O.E. The importance of mineral elements for humans, domestic animals and plants: A review. Afr. J. Food Sci. 2010, 4, 200-222.

33. Gil, R.; Lull, C.; Boscaiu, M.; Bautista, I.; Lidón, A.; Vicente, O. Soluble carbohydrates as osmolytes in several halophytes from a mediterranean salt marsh. Not. Bot. Horti Agrobot. Cluj-Napoca 2011, 39, 9-17. [CrossRef]

34. USDA. FoodData Central Search results. Pork 2019, 9, 1.

35. Balafrej, H.; Bogusz, D.; Triqui, Z.-E.A.; Guedira, A.; Bendaou, N.; Smouni, A.; Fahr, M. Zinc hyperaccumulation in plants: A review. Plants 2020, 9, 562. [CrossRef] [PubMed]

36. Beltrao, J.; Neves, A.; De Brito, J.C.; Seita, J. Salt removal potential of turfgrass in golf courses in the mediterranean Basin. WSEAS Trans. Environ. Dev. 2009, 5, 394-403.

37. Commission, E. Commission Regulation (EU) 2015/1005 of 25 June 2015 Amending Regulation (EC) No 1881/2006 as Regards Maximum Levels of Lead in Certain Foodstuffs. Available online: https://eur-lex.europa.eu/legal-content/EN/TXT/?uri= CELEX\%3A32015R1005 (accessed on 13 June 2021).

38. Fitzpatrick, T.B.; Chapman, L.M. The importance of thiamine (vitamin B1) in plant health: From crop yield to biofortification. J. Biol. Chem. 2020, 295, 12002-12013. [CrossRef] [PubMed]

39. Tunc-Ozdemir, M.; Miller, G.; Song, L.; Kim, J.; Sodek, A.; Koussevitzky, S.; Misra, A.N.; Mittler, R.; Shintani, D. Thiamin confers enhanced tolerance to oxidative stress in Arabidopsis. Plant Physiol. 2009, 151, 421-432. [CrossRef]

40. Chamkouri, N.; Asgari, T.; Ghasemi, M. Research Article Determination multi-element concentrations in Suaeda vera by ICP OES. J. Chem. Pharm. Res. 2015, 7, 191-194.

41. Nan, M.; Pintea, A.; Bunea, A.; Esianu, S.; Tamas, M. HPLC analysis of carotenoids from Inula helenium L. flowers and leaves. Farmacia 2012, 60, 501-509.

42. Rabhi, M.; Castagna, A.; Remorini, D.; Scattino, C.; Smaoui, A.; Ranieri, A.; Abdelly, C. Photosynthetic responses to salinity in two obligate halophytes: Sesuvium portulacastrum and Tecticornia indica. S. Afr. J. Bot. 2012, 79, 39-47. [CrossRef]

43. Reginato, M.A.; Castagna, A.; Furlán, A.; Castro, S.; Ranieri, A.; Luna, V. Physiological responses of a halophytic shrub to salt stress by $\mathrm{Na}_{2} \mathrm{SO}_{4}$ and $\mathrm{NaCl}$ : Oxidative damage and the role of polyphenols in antioxidant protection. AoB Plants 2014, 6, 1-13. [CrossRef] 
44. Falleh, H.; Trabelsi, N.; Bonenfant-Magné, M.; Le Floch, G.; Abdelly, C.; Magné, C.; Ksouri, R. Polyphenol content and biological activities of Mesembryanthemum edule organs after fractionation. Ind. Crops Prod. 2013, 42, 145-152. [CrossRef]

45. Alhdad, G.M.; Seal, C.E.; Al-Azzawi, M.J.; Flowers, T.J. The effect of combined salinity and waterlogging on the halophyte Suaeda maritima: The role of antioxidants. Environ. Exp. Bot. 2013, 87, 120-125. [CrossRef]

46. Bueno, M.; Lendínez, M.L.; Calero, J.; del Pilar Cordovilla, M. Salinity responses of three halophytes from inland saltmarshes of Jaén (southern Spain). Flora Morphol. Distrib. Funct. Ecol. Plants 2020, 266, 151589. [CrossRef]

47. Adnan, M.Y.; Hussain, T.; Asrar, H.; Hameed, A.; Gul, B.; Nielsen, B.L.; Khan, M.A. Desmostachya bipinnata manages photosynthesis and oxidative stress at moderate salinity. Flora Morphol. Distrib. Funct. Ecol. Plants 2016, 225, 1-9. [CrossRef]

48. Slama, I.; M'Rabet, R.; Ksouri, R.; Talbi, O.; Debez, A.; Abdelly, C. Effects of salt treatment on growth, lipid membrane peroxidation, polyphenol content, and antioxidant activities in leaves of Sesuvium portulacastrum L. Arid Land Res. Manag. 2017, 31, 404-417. [CrossRef]

49. Ainsworth, E.A.; Gillespie, K.M. Estimation of total phenolic content and other oxidation substrates in plant tissues using Folin-Ciocalteu reagent. Nat. Protoc. 2007, 2, 875-877. [CrossRef]

50. Everette, J.D.; Bryant, Q.M.; Green, A.M.; Abbey, Y.A.; Wangila, G.W.; Walker, R.B. Thorough study of reactivity of various compound classes toward the folin-Ciocalteu reagent. J. Agric. Food Chem. 2010, 58, 8139-8144. [CrossRef]

51. Cristofoli, N.L.; Lima, C.A.R.; Vieira, M.M.C.; Andrade, K.S.; Ferreira, S.R.S. Antioxidant and antimicrobial potential of cajazeira leaves (Spondias mombin) extracts. Sep. Sci. Technol. 2019, 54, 580-590. [CrossRef]

52. Doudach, L.; Meddah, B.; Benbacer, L.; Hammani, K.; El, M.; Verité, P. Ethnopharmacological studies of Mesembryanthemum nodiflorum. Phytopharmacology 2013, 4, 246-258.

53. Barreira, L.; Resek, E.; Rodrigues, M.J.; Rocha, M.I.; Pereira, H.; Bandarra, N.; da Silva, M.M.; Varela, J.; Custódio, L. Halophytes: Gourmet food with nutritional health benefits? J. Food Compos. Anal. 2017, 59, 35-42. [CrossRef]

54. Leshem, M. Biobehavior of the human love of salt. Neurosci. Biobehav. Rev. 2009, 33, 1-17. [CrossRef] [PubMed]

55. Liem, D.G.; Miremadi, F.; Keast, R.S.J. Reducing Sodium in Foods: The Effect on Flavor. Nutrients 2011, 694-711. [CrossRef]

56. Gaudette, N.J.; Pietrasik, Z. The impact of sodium reduction strategies on the sensory and processing characteristics of meat products. MESC 2013, 96, 123. [CrossRef]

57. Pravdova, V.; Boucon, C.; De Jong, S.; Walczak, B.; Massart, D.L. Three-way principal component analysis applied to food analysis: An example. Anal. Chim. Acta 2002, 462, 133-148. [CrossRef]

58. Hoather, R.C.; Rackham, R.F. Oxidised nitrogen in waters and sewage effluents observed by ultra-violet spectrophotometry. Analyst 1959, 84, 548-551. [CrossRef]

59. Bligh, E.G.; Dyer, W.J. Canadian Journal of Biochemistry and Physiology. Can. J. Biochem. Physiol. 1959, 37, 911-917. [CrossRef]

60. McCleary, B.V.; Mills, C.; Draga, A. Development and evaluation of an integrated method for the measurement of total dietaryfibre. Qual. Assur. Saf. Crop. Foods 2009, 1, 213-224. [CrossRef]

61. Taniwaki, M.; Takahashi, M.; Sakurai, N.; Takada, A.; Nagata, M. Effects of harvest time and low temperature storage on the texture of cabbage leaves. Postharvest Biol. Technol. 2009, 54, 106-110. [CrossRef]

62. Santos, J.; Mendiola, J.A.; Oliveira, M.B.P.P.; Ibáñez, E.; Herrero, M. Sequential determination of fat- and water-soluble vitamins in green leafy vegetables during storage. J. Chromatogr. A 2012, 1261, 179-188. [CrossRef]

63. Klejdus, B.; Petrlová, J.; Potěšil, D.; Adam, V.; Mikelová, R.; Vacek, J.; Kizek, R.; Kubáň, V. Simultaneous determination of waterand fat-soluble vitamins in pharmaceutical preparations by high-performance liquid chromatography coupled with diode array detection. Anal. Chim. Acta 2004, 520, 57-67. [CrossRef]

64. Re, R.; Pellegrini, N.; Proteggente, A.; Pannala, A.; Yang, M.; Rice-Evans, C. Antioxidant activity applying an improved ABTS radical cation decolorization assay. Free Radic. Biol. Med. 1999, 26, 1231-1237. [CrossRef]

65. Moreno, S.; Scheyer, T.; Romano, C.S.; Vojnov, A.A. Antioxidant and antimicrobial activities of rosemary extracts linked to their polyphenol composition. Free Radic. Res. 2006, 40, 223-231. [CrossRef] [PubMed]

66. Velioglu, Y.S.; Mazza, G.; Gao, L.; Oomah, B.D. Antioxidant Activity and Total Phenolics in Selected Fruits, Vegetables, and Grain Products. J. Agric. Food Chem. 1998, 46, 4113-4117. [CrossRef]

67. Li, Y.G.; Tanner, G.; Larkin, P. The DMACA-HCl protocol and the threshold proanthocyanidin content for bloat safety in forage legumes. J. Sci. Food Agric. 1996, 70, 89-101. [CrossRef]

68. Zou, Y.; Chang, S.K.C.; Gu, Y.; Qian, S.Y. Antioxidant activity and phenolic compositions of lentil (Lens culinaris var. Morton) extract and its fractions. J. Agric. Food Chem. 2011, 59, 2268-2276. [CrossRef]

69. Stone, H.; Bleibaum, R.N.; Thomas, H.A. Descriptive Analysis. In Sensory Evaluation Practices; Academic Press: Cambridge, UK, 2012; pp. 233-289. ISBN 9780123820860.

70. Stone, H.; Sidel, J.; Oliver, S.; Woolsey, A.; Singleton, R.C. Qauntitative Descriptive Analysis. In Descriptive Sensory Analysis in Practice; Gacula, M.C., Jr., Ed.; Food \& Nutrition Press, Inc: Scottsdale, AZ, USA, 2004; pp. 24-32. ISBN 9780470385036. 